\title{
Prey selection by larval haddock and cod on copepods with species-specific behavior: an individual-based model analysis
}

\author{
Colleen M. Petrik ${ }^{1, *}$, Trond Kristiansen ${ }^{2}$, R. Gregory Lough ${ }^{3}$, Cabell S. Davis ${ }^{1}$ \\ ${ }^{1}$ Biology Department, Woods Hole Oceanographic Institution, Woods Hole, Massachusetts 02543, USA \\ ${ }^{2}$ Institute of Marine Research, PO Box 1870 Nordnes, 5817 Bergen, Norway \\ ${ }^{3}$ Northeast Fisheries Science Center, NMFS, NOAA, Woods Hole, Massachusetts 02543, USA
}

\begin{abstract}
Coupled biological-physical models of larval fish have become a widely used tool for studying recruitment variability. Within these models, foraging components include prey selection as a determinant of food availability but have not yet considered species-specific escape behaviors of prey, which can be important in determining capture success. Furthermore, there has been extensive work on some species (e.g. cod Gadus morhua), but less on others (e.g. haddock Melanogrammus aeglefinus). We collected information from the literature on the escape behaviors of the copepods Calanus finmarchicus, Pseudocalanus spp., Oithona similis, and Centropages typicus, the dominant prey of larval haddock and cod on Georges Bank (NW Atlantic), for use in a mechanistic foraging model. The foraging model was coupled to a bioenergetics model to simulate larval haddock and cod feeding and growth. Larval haddock and cod demonstrated positive selection of Pseudocalanus spp. and negative selection of $C$. finmarchicus based on modeled Chesson's preference index. Speciesspecific differences in escape abilities affected selection more than encounter rate. Prey escape behavior explained why larval cod rarely feed on C. typicus, although these prey items are numerous in the water column. Disparities between larval haddock and cod in their simulated prey selection and growth rates were the result of different mouth sizes and metabolisms. Simulated haddock foraging agreed with gut content observations of the size and species composition of ingested prey. These models are the first to describe haddock foraging and to include species-specific prey behaviors.
\end{abstract}

KEY WORDS: Individual-based model · Foraging - Escape behavior $\cdot$ Haddock $\cdot$ Cod $\cdot$ Copepods . Larval fish · Georges Bank

\section{INTRODUCTION}

Survival and thereby recruitment of fish is largely determined during the first 6 mo after hatch (Houde 1987, Sundby et al. 1989). During this period, survival is affected by biological and physical conditions controlling the ability of larvae to find food in the water column. To study these processes, foraging models have been used in coupled biological-physical individual-based models (IBMs) of larval fish. Incorporating mechanistic feeding components into IBMs makes it possible to examine the foraging process in relation to key environmental conditions such as stratification, turbulence, and prey patchiness.

The foraging process itself is quite complex. For any predator, consumption rate is the product of encounter rate and capture success (Bailey \& Houde 1989). Larval fish foraging follows a particular behavioral sequence: (1) encounter, (2) pursuit, (3) attack/capture, and (4) ingestion (MacKenzie \& Kiørboe 2000). Encounter is defined as the detection of the prey and is a function of prey density, the relative velocities of predator and 
prey, and the visibility of the prey (Rothschild \& Osborn 1988, Bailey \& Houde 1989, MacKenzie \& Kiørboe 2000, Fiksen \& MacKenzie 2002). Capture success is influenced by the predator's swimming speed and mouth size, the turbulent velocity, and the prey's ability to detect and respond to a predator during the pursuit or attack (Bailey \& Houde 1989, MacKenzie \& Kiørboe 2000). During the pursuit the larva swims towards the prey until: (1) the larva attacks the prey, (2) the prey escapes and the larva does not follow it, or (3) the prey is advected away and the larva does not follow it (MacKenzie \& Kiørboe 2000). An attack occurs when the fish larva opens its mouth to capture and ingest the prey (MacKenzie \& Kiørboe 2000). For cod Gadus morhua, this involves sucking in a volume of water and the prey within it (MacKenzie \& Kiørboe 1995). Capture has occurred once the prey is in the mouth of the larva, and it is followed by ingestion (MacKenzie et al. 1994). The process of larval fish feeding on copepods has been mechanistically modeled by Caparroy et al. (2000) and adapted for larval cod by Fiksen \& MacKenzie (2002).

The ability of a fish larva to capture copepod prey depends on the copepod species, even when the copepods are the same size (Munk 1997), because escape behaviors vary between copepod species (Tiselius \& Jonsson 1990, Viitasalo et al. 1998, Titelman 2001, Titelman \& Kiørboe 2003). Copepods possess adaptations to reduce their vulnerability to predation, including mechanoreceptors on their setae that detect the hydrodynamic signals produced by predators (Haury et al. 1980, Yen et al. 1992). The signal that copepods perceive is the deformation rate of the fluid (Kiørboe \& Visser 1999). A deformation rate above a certain threshold will elicit an escape 'jump' (Kiørboe \& Visser 1999), where a copepod orients itself away from the predator and jumps at a speed 50 to 200 times greater than its average swimming speed (Mauchline 1998, Titelman \& Kiørboe 2003, Waggett \& Buskey 2007). The deformation rate threshold, escape jump angle, and escape jump speed are all species- and stage-specific (Tiselius \& Jonsson 1990, Viitasalo et al. 1998, Titelman 2001, Titelman \& Kiørboe 2003).

On Georges Bank (NW Atlantic) the 4 main copepod prey items of the larval gadids cod and haddock are Calanus finmarchicus, Pseudocalanus spp., Oithona similis, and Centropages typicus (Kane 1984). From gut observations of both cod and haddock, it is evident that not all potential prey species are found in the larval gut. Larval cod and haddock prefer Pseudocalanus spp., while Centropages typicus and $O$. similis are ingested less than in proportion to their abundance in the water column, and Calanus finmarchicus is rarely selected because of its large size (Kane 1984, Heath \& Lough 2007, Broughton \& Lough in press).
Until recently, most models of larval cod and haddock feeding have assigned stages of copepod species to different larval size classes as possible prey targets based on gut contents or the mouth gape of the larvae and width of the copepods. Current trophodynamic models of larval cod (Kristiansen et al. 2007, 2009b) include a mechanistic foraging component where encounter rate, pursuit success, and capture success determine ingestion. Kristiansen et al. (2009b) used an IBM with a mechanistic feeding component that included species-specific size information, but escape behaviors were limited to escape speed that was parameterized for the copepod Acartia tonsa. These model experiments were unable to explain why Centropages typicus is not a preferred prey item for larval cod. The authors suggested this disparity could be caused by a different behavioral strategy between Pseudocalanus spp. and C. typicus (which are similar in size). We expand on the Kristiansen et al. (2009b) model by including species- and stage-specific escape behaviors to determine which species and life stages of copepods larval haddock and cod can capture, and how this influences energy gained, growth, and thereby chances of survival.

An accurate understanding of foraging in haddock and cod larvae is important, since growth of both species is strongly dependent on the availability of copepod prey (Buckley \& Durbin 2006). The larval diets of these closely related species overlap significantly on Georges Bank (Kane 1984, Broughton \& Lough in press). However, the guts of haddock larvae typically contain earlier stages of copepods, smaller prey, and less biomass than the guts of cod larvae of the same size (Kane 1984, Lough \& Mountain 1996, Rowlands et al. 2008). The fin development of larvae 8 to $9 \mathrm{~mm}$ is more advanced in haddock than cod. Auditore et al. (1994) suggest that the advanced fin development may give haddock more maneuverability for setting up precise feeding strikes and selecting smaller prey. The feeding behavior of larval cod has been well characterized (MacKenzie \& Kiørboe 1995, Munk 1995, Fiksen et al. 1998, Hunt von Herbing \& Gallager 2000, Ruzicka 2004, Ruzicka \& Gallager 2006a, 2006b), but mechanistic feeding studies of larval haddock are lacking. Here we explore the differences between larval haddock and cod prey selection by modeling foraging behavior in both species.

Our objectives are to (1) use information on the morphology and physiology of larval haddock to create the first coupled mechanistic foraging and bioenergetics model for this species, (2) use speciesspecific prey behaviors in foraging models of both larval haddock and cod, and (3) examine why certain copepod species are positively or negatively selected as prey. 


\section{MATERIALS AND METHODS}

The model. The model description follows the overview, design, details (ODD) protocol for describing individual- and agent-based models (Grimm \& Railsback 2005, Grimm et al. 2006) and consists of 7 elements. The first 3 elements provide an overview, the 4 th element explains general concepts underlying the model's design, and the remaining 3 elements provide details.

Purpose. The purpose of our IBM was to improve our understanding of the complex feeding ecology of larval haddock and cod on Georges Bank. This included the interaction between copepod size/escape behavior, larval fish feeding behavior, and the abiotic environment. Analysis of the feeding ecology was made possible using a mechanistic feeding component that accounted for the processes of prey encounter, pursuit, and capture. Species-specific copepod behaviors were included in the foraging component to improve on previous work of larval cod prey selection (Kristiansen et al. 2009b). Additionally, the IBM was parameterized for larval haddock to investigate whether the model could capture the differences between larval haddock and cod diets. A bioenergetics component of the IBM was used to examine the effects of feeding on growth. In these short numerical experiments larvae did not die. They were not preyed upon, nor did they die from starvation, so the potential effects of only the fittest larvae surviving were not examined here.

State variables and scales. The model environment was a 1-dimensional water column $70 \mathrm{~m}$ deep and divided into discrete $1 \mathrm{~m}$ depth intervals. Each depth layer was characterized by temperature, light, turbulence, and prey abundance, all of which varied with time. The IBM simulated individual larval fish that were described by the state variables: species, length, weight, depth, gut size, stomach fullness, and growth rate. Prey items were identified by species (4 total: Calanus finmarchicus, Pseudocalanus spp., Oithona similis, and Centropages typicus), stage (13 total: 6 naupliar stages, NI to NVI; 5 copepodite stages, CI to $\mathrm{CV}_{\text {; }}$ and 1 adult stage separated into females and males, CVIf and CVIm), length, width, weight, and concentration. The model was run for $108 \mathrm{~h}$ (4.5 d) with a time step of $1 \mathrm{~h}$.

Process overview and scheduling. For each time step, the environmental variables were updated, and then the foraging and bioenergetics components were run sequentially. Within a component, individuals were called one at a time by depth, starting at $1 \mathrm{~m}$ and ending at $70 \mathrm{~m}$. Within the foraging component, the steps of encounter, pursuit, and capture were simulated in that order, for each individual and for each species and stage of copepod. The capture process was repeated 1000 times for each individual larva and prey type to calculate a probability of successful capture. Total biomass captured by each individual for each time step was stored in the stomach, and used in the bioenergetics component to calculate energy needed to sustain metabolism. The remaining energy in the stomach was then used to calculate growth.

Design concepts. Emergence: Prey preference, a measure of what prey types an individual ingests compared to the prey types available in its environment, emerged from the mechanistically modeled foraging process of each individual fish. Additionally, the average growth rate arose from the foraging activities of all individuals.

Sensing: Visual detection of prey was light-dependent. Though larvae could not sense the deformation threshold of each copepod prey type, the approach speed was modeled to be less than that which would elicit an escape response.

Interaction: Individual larvae were assumed not to interact with each other due to their observed sparseness in nature and lack of grazing pressure on their prey populations (Pepin \& Penney 2000), thus there were no density-dependent responses and larvae were assumed not to reduce the prey density by feeding. Based on laboratory observations, we assumed that each species and stage of copepod prey was encountered and pursued, and potentially captured and ingested, one at a time. Encounter was a function of prey concentration, among other variables; it was not determined by explicitly modeling the position of each copepod relative to each larval fish.

Stochasticity: Within the foraging subroutine, probabilities of encounter, successful approach, and successful capture were used to compute the total prey ingested. The probabilities of encounter and successful approach were calculated from theoretical equations (Caparroy et al. 2000, Fiksen \& MacKenzie 2002, Kristiansen et al. 2007, 2009b). The probability of successful capture was determined from 1000 attempts of capturing each copepod species and stage. During each capture attempt, the escape jump angle of a copepod was drawn from a normal distribution with mean specific to that species and an $\mathrm{SD}$ of $30^{\circ}$, where $0^{\circ}$ was directly away from the mouth of the larval fish.

Observation: Every hour, for each individual, observations were made of all the larval state variables, the probability of successful capture of each prey item, the total number of each species and stage of prey ingested, the length and width of each prey item ingested, the total biomass ingested, and the larval growth rate.

Initialization. The model was initialized with 1 larval fish fixed at each $1 \mathrm{~m}$ depth position from surface to bottom for a total of 70 . All model simulations were repeated for 5 initial larval standard lengths: 5, 7, 9, 11, 
or $15 \mathrm{~mm}$, spanning the range of larval/early juvenile sizes measured on Georges Bank. Stomach fullness was initialized at $10 \%$ to ensure hunger, but avoid effects of immediate starvation. Model simulations were run from 13:00 h local time on 22 May to 24:00 h on 27 May for both 1993 and 1994. This period was chosen to take advantage of an existing field data set used to force the model and compared with model results (Lough et al. 2005). Several simulations were conducted to examine differences between years, differences between cod and haddock, and sensitivity to parameterization of foraging behaviors. Because the effects of stochasticity (escape jump angle) on prey ingested and growth rate were so small, the results of 1 simulation run are presented here.

Input. In situ temperature and prey concentration and modeled light and turbulence served as model input. Temperature and prey concentration were measured on the seasonally stratified southern flank of Georges Bank in May of 1993 and 1994 in a study that tracked a cohort of larvae with a drifter at $13 \mathrm{~m}$ depth (Lough et al. 2005). Temperature from conductivity, temperature, depth (CTD) observations and prey concentration from Multiple Opening/Closing Net and Environmental Sampling System (MOCNESS) collections were interpolated in space and time to produce values for each depth and each hour over the $4.5 \mathrm{~d}$. Surface light was modeled as a function of the day of the year and latitude (Skartveit et al. 1998), which was used with a constant attenuation coefficient $(k=0.18)$ to calculate exponentially decaying light at depth. Turbulence was calculated from a 1-dimensional model for Georges Bank forced by winds, hydrographic conditions, and the $\mathrm{M}_{2}$ tide (Naimie 1996).

Submodels. Foraging: The mechanistic feeding component of the IBM was built on previous work by Caparroy et al. (2000) and Fiksen \& MacKenzie (2002), and is described in detail in Kristiansen et al. (2007, $2009 \mathrm{~b})$. The foraging submodel sequentially simulated the encounter, pursuit, and capture of prey by larval fish. Encounter occurs in front of the larva's head in a hemisphere volume with radius equal to the perception distance. The visual perception of a prey item is determined by larval size, light level, water quality between the prey and the larva (beam attenuation coefficient), prey contrast, and prey image area. Haddock and cod larvae move in a 'pause-travel' pattern (Evans \& O'Brien 1988). During the pause, the larva encounters a prey item that resides in the hemisphere in front of its head. Encounter between prey and predator is also achieved if the prey swims, or is advected by turbulence into the larval visual hemisphere during pause. These methods of encounter depend on the prey density, larval visual abilities (size and light-level dependent), prey swimming speed, and turbulent velocity. The larva will try to pursue all prey encountered. To avoid being detected by the prey, the larva always pursues at a speed that ensures that the resulting shear is below the sensitivity threshold of the prey. A copepod escapes during pursuit if the larva takes too long to reach it. The larva must travel at the undetectable speed and reach the copepod in $<10 \mathrm{~s}$, the average pursuit time measured in laboratory experiments (see Fiksen \& MacKenzie 2002). Thus, successful pursuit is controlled by the sensitivity threshold of that prey type, and the encounter distance between prey and predator. Also during pursuit, the prey can be advected by turbulence out of the perception volume of the larva (MacKenzie \& Kiørboe 2000). If the larva reaches the prey without detection or without loss by turbulent advection it reaches the attack position a short distance from the prey. During larval attack, the copepod has one last chance to escape by jumping, with its specific speed and angle, out of the volume of water that will be engulfed by the larva. If the prey remains within visual detection of the larva, the larva will try again to capture it, up to 3 times.

The mechanistic feeding component of the IBM is the same as described in Kristiansen et al. (2009b), with the exception that we included species-specific swimming and escape behaviors (swimming speed, detection threshold, escape jump angle, escape jump speed) for the dominant prey items Calanus finmarchicus, Pseudocalanus spp., Oithona similis, and Centropages typicus (see 'Copepod parameterization' below). Furthermore, the mouth gape parameter, $m$ $(\mathrm{mm})$, differed between simulations of $\operatorname{cod}\left(m_{c}\right)$ and haddock $\left(m_{h}\right)$ as follows:

$$
\begin{gathered}
m_{C}=\exp \left(-3.720+1.818 \times \ln (L)-0.1219 \times \ln (L)^{2}\right) \\
m_{h}=0.128 \times L^{0.923}
\end{gathered}
$$

where $L$ is standard length in $\mathrm{mm}$. The mouth gape sizes were empirically derived by Otterå \& Folkvord (1993) for cod and Rowlands et al. (2006) for haddock.

Bioenergetics: After the ingested prey items have been stored in the stomach from the feeding component, the IBM uses a bioenergetics component to calculate growth and metabolism. The details of this model can be found in Kristiansen et al. (2007) with the only difference being the respiration rate. Rather than using the respiration rate of Finn et al. (2002), we modeled the routine respiration rate as described in Lough et al. (2005), which was measured on larval cod from the Georges Bank population. The routine respiration rate applied in the larval haddock simulations was from a laboratory study by Lankin et al. (2008), and, like cod, was measured on fish from Georges Bank at temperatures of 4,7 , and $10^{\circ} \mathrm{C}$. The routine respiration rates $\left(\mu \mathrm{l} \mathrm{O}_{2} \mathrm{fish}^{-1} \mathrm{~h}^{-1}\right)$ of $\operatorname{cod}\left(R_{c}\right)$ and haddock $\left(R_{h}\right)$ are 


$$
\begin{gathered}
R_{C}=0.00114 \times W^{(1.029-0.00774 \times \ln (W))} \times \exp (T \times \\
(0.10720-0.00320 \times \ln (W))) \\
R_{h}=1.021 \times(W \times 1000)^{0.979} \times \exp (0.092 \times T)
\end{gathered}
$$

where $W$ is dry weight in $\mu$ g, and $T$ is temperature in ${ }^{\circ} \mathrm{C}$. When light was below the threshold value of $0.01 \mu \mathrm{mol} \mathrm{s}{ }^{-1} \mathrm{~m}^{-2}$ it was regarded as too dark to feed and the routine respiration was used in the bioenergetic calculations. Above this threshold we invoked an active metabolism of $1.4 \times R$ for larvae $<5.5 \mathrm{~mm}$ and $2.5 \times R$ for larvae $>5.5 \mathrm{~mm}$ (Lough et al. 2005). Growth was either temperature- and food-dependent or just temperature-dependent determined by the amount of biomass stored in the stomach. The amount of biomass ingested in the foraging subroutine was stored in the gut, and not allowed to exceed the capacity of the gut. If this amount of biomass was enough for maximum growth, as determined by weight, respiration rate and assimilation rate, then growth was the maximum temperature-dependent rate. If the biomass in the gut was below this amount, it was converted into body mass and growth was food-limited.

Copepod parameterization. The copepod parameters necessary for use in the mechanistic foraging model were image area, contrast, swimming speed, deformation rate threshold, escape jump speed, and escape jump angle. The image area of all species and stages was calculated for elongate prey as a function of copepod length and width (area $=0.75 \times$ length $\times$ width). Information on species-specific contrast was lacking, thus all species and stages were assumed to have the same value (0.3; Utne-Palm 1999) used to represent moderately transparent prey $0.1=$ transparent, 1.0 = black; Fiksen et al. 1998). Species- and stagespecific information on swimming speed, deformation rate threshold, escape jump speed, and escape jump angle of Calanus finmarchicus, Pseudocalanus spp., Oithona similis, and Centropages typicus was gathered from the literature. The literature comprised laboratory experiments of moving tanks with obstacles (Haury et al. 1980), stationary tanks with siphons (Fields \& Yen 1997, Viitasalo et al. 1998, 2001, Kiørboe et al. 1999, Titelman 2001, Titelman \& Kiørboe 2003), and tanks with predators (Greene et al. 1986, Tiselius \& Jonsson 1990, Viitasalo et al. 1998, Svensen \& Kiørboe 2000, Titelman 2001). The experiments recorded behaviors with video and then measured the behaviors by digital analysis.

We were not able to find data for each stage of each species for every behavior, nor was there enough data to individually fit equations to determine the behaviors as functions of stage or size. To solve this problem we assumed that mean escape jump angle was constant for a given species and that deformation rate threshold, swimming speed, and escape jump speed were proportional to length. Justification for this assumption comes from Kiørboe \& Visser (1999) who showed that the deformation rate threshold scales inversely with size, while swimming speed and escape speed are often reported in body lengths (BL) $\mathrm{s}^{-1}$ because they increase with prey size (Mauchline 1998, Caparroy et al. 2000). Some copepods have a hop-sink motility (Mauchline 1998, Titelman 2001, Titelman \& Kiørboe 2003) with 2 associated speeds. This motility was represented as 1 swimming speed by averaging the hop speed and sinking speed by the proportion of time spent performing each behavior.

Values for the behaviors were often listed in the literature for 1 developmental stage only or for a group of stages. Linear regressions of escape behavior as a function of length were created by assigning the average prosome length (Davis 1984, 1987) to each developmental stage. If 1 value of a behavior was given for a group of stages (e.g. NI to NIII) that value was used for each stage within that group. Because for certain behaviors there was only 1 value reported for 1 stage of a species, all regressions were assumed to intercept the origin.

Information on certain behaviors was lacking altogether for some species. The genus Pseudocalanus on Georges Bank comprises P. moultoni and P. newmani (McGillicuddy \& Bucklin 2002), which we parameterized using data for the closely related $P$. elongatus. Swimming speeds of a related species, Calanus pacificus, were used to fit a linear regression to the $C$. finmarchicus lengths. This method resulted in a swimming speed of $1.97 \mathrm{BL} \mathrm{s}^{-1}$, which is equivalent to the $2 \mathrm{BL} \mathrm{s}^{-1}$ found by Hardy \& Bainbridge (1954 in Mauchline 1998) for $C$. finmarchicus nauplii. It is a conservative estimate for copepodites and adults that have been reported to swim up to $5 \mathrm{BL} \mathrm{s}^{-1}$ (Mauchline 1998). The literature on Oithona similis escape speed provided the average velocities of initial escape attempts (47.2 $\left.\mathrm{BL} \mathrm{s}^{-1}\right)$ and the final escape attempt (77.0 BL s${ }^{-1}$ ) that freed the individual from siphon flow (Fields 2000). The average of escape speed of the other 3 copepod species in BL s ${ }^{-1}\left(74.1 \mathrm{BL} \mathrm{s}^{-1}\right)$ was closer to the final escape attempt speed of $O$. similis, and this average was used in the simulations. Finally, there was no information on $O$. similis or Pseudocalanus spp. escape angle. Escape angles for $O$. similis and Pseudocalanus spp. were assumed to be $30^{\circ}$ (0.524 radians), the value used by Fiksen \& MacKenzie (2002) that they adapted from results in Titelman (2001). The equations for copepod escape behavior and their sources are given in Table 1. We recognize that copepod behavior is more complex than what is represented by these functions; however, they are a first attempt at incorporating species-specific copepod behavior into larval fish foraging models. 
Larval haddock parameterization. Like cod, haddock is a saltatory (pause-travel) forager (Auditore et al. 1994). Saltatory foraging is distinguished by a swimming burst used to move to a new search location, a glide while the larva slows down, and a pause, during which the larva searches for prey (Evans \& O'Brien 1988). Behavioral characteristics of the saltatory foraging strategy include burst speed, burst duration (BD), pause duration (PD), and pause frequency $(\mathrm{PF})$. These characteristics have been measured for cod (MacKenzie \& Kiørboe 1995, Munk 1995, Fiksen et al. 1998, Hunt von Herbing \& Gallager 2000, Ruzicka \& Gallager 2006b), but not for haddock. Therefore, larval haddock foraging behavior must be inferred from unpublished studies of haddock and published information about number, type, and biomass of prey ingested.

Laurence (1985) defines search capacity as the product of the larval swimming speed and the crosssectional area of its perception volume, and reports that larval haddock has a lower search capacity as a function of weight in comparison to cod larvae. However, in studies of larval haddock and cod (Werner et al. 1996, Lough et al. 2005), length is used as a measure of age rather than weight because their mean length at age is equivalent (Bolz \& Lough 1988). At a given length, a larval haddock weighs more than cod (Fig. 1a). Thus, the search capacities of haddock and cod as a function of length, a proxy for age, are relatively equal (Fig. 1b). The search volume geometry of cod has been approximated as a hemisphere (Hunt von Herbing \& Gallager 2000, Fiksen \& MacKenzie 2002). In contrast, unpublished laboratory observations (H. Browman unpubl. data) led Galbraith et al. (2004) to conclude that the search volume geometry of a $6 \mathrm{~mm}$ cod larva is a wedge. However, the different perception distances used with each search volume geometry result in equivalent volumes of water searched (Ruzicka \& Gallager 2006a). Additionally, Mariani et al. (2007) found that model results using hemisphere geometry were more consistent with laboratory and field observations of larval cod. Taking into account the equivalent search capacities of cod and haddock, we assumed that the swimming speed and perception distance of haddock and cod could be treated as equal for a given length, and that their search geometry was hemispherical. If larval haddock eat significantly smaller prey than cod then that must be attributed to differences in metabolism, mouth size, and other aspects of foraging behavior such as PD and PF.

To understand the sensitivity of haddock gut contents to changes in foraging behavior, 3 different simulations were completed using different sets of parameters, but forced by the same environmental conditions from May 1993. All 3 used mouth size as a function of length from Rowlands et al. (2006; our Eq. 2) and a length-weight re-

Table 1. Calanus finmarchicus, Pseudocalanus spp., Oithona similis, and Centropages typicus. Functions for copepod escape behavior. L: body length (mm), NI to NVI: 6 naupliar stages, CI to CV: 5 copepodite stages, CVI: adult stage

\begin{tabular}{|c|c|c|c|c|}
\hline Species & Parameter & Function & Species: stages & Source \\
\hline \multicolumn{5}{|c|}{ C. finmarchicus } \\
\hline & Swimming speed $\left(\mathrm{mm} \mathrm{s}^{-1}\right)$ & $1.97 \times \mathrm{L}$ & C. pacificus: NII-NIII, NV-CVI & Greene et al. (1986) \\
\hline & Escape speed $\left(\mathrm{mm} \mathrm{s}^{-1}\right)$ & $74.5 \times \mathrm{L}$ & C. finmarchicus: CIV-CV & Haury et al. (1980) \\
\hline & Sensitivity threshold $\left(\mathrm{s}^{-1}\right)$ & $1.00 \times \mathrm{L}^{-1}$ & C. finmarchicus: CV & Kiørboe et al. (1999) \\
\hline & Escape jump angle (rad) & 1.13 & C. finmarchicus: CIV-CV & Haury et al. (1980) \\
\hline \multicolumn{5}{|c|}{ Pseudocalanus spp. } \\
\hline & Swimming speed $\left(\mathrm{mm} \mathrm{s}^{-1}\right)$ & $0.859 \times \mathrm{L}$ & P. elongatus: CII-CIV, CVI & Tiselius \& Jonsson (1990) \\
\hline & & & Pseudocalanus spp.: NIII-CI & Landry \& Fagerness (1988) \\
\hline & Escape speed $\left(\mathrm{mm} \mathrm{s}^{-1}\right)$ & $57.3 \times \mathrm{L}$ & P. elongatus: CI-CVI & Viitasalo et al. (2001) \\
\hline & Sensitivity threshold $\left(\mathrm{s}^{-1}\right)$ & $2.78 \times \mathrm{L}^{-1}$ & P. elongatus ${ }^{\mathrm{a}}$ : CI-CVI & Viitasalo et al. (2001) \\
\hline & Escape jump angle (rad) & 0.524 & - & - \\
\hline \multicolumn{5}{|l|}{ O. similis } \\
\hline & $\begin{array}{l}\text { Swimming speed }\left(\mathrm{mm} \mathrm{s}^{-1}\right) \\
\text { Escape speed }\left(\mathrm{mm} \mathrm{s}^{-1}\right)\end{array}$ & $\begin{array}{l}0.708 \times \mathrm{L} \\
74.1 \times \mathrm{L}\end{array}$ & $\begin{array}{c}\text { Oithona sp.: CVI } \\
-\end{array}$ & $\begin{array}{c}\text { Svensen \& Kiørboe (2000) } \\
\text { _ }\end{array}$ \\
\hline & Sensitivity threshold $\left(\mathrm{s}^{-1}\right)$ & $2.66 \times \mathrm{L}^{-1}$ & Oithona sp.: CVI & Kiørboe et al. (1999) \\
\hline & Escape jump angle (rad) & 0.524 & - & - \\
\hline \multirow{5}{*}{ C. typicus } & Swimming speed $\left(\mathrm{mm} \mathrm{s}^{-1}\right)$ & $1.301 \times \mathrm{L}$ & C. typicus: CIV-CV; & Tiselius \& Jonsson (1990) \\
\hline & & & C. typicus: NI-NII, NIV-NV, CVI & Titelman \& Kiørboe (2003) \\
\hline & Escape speed $\left(\mathrm{mm} \mathrm{s}^{-1}\right)$ & $90.6 \times \mathrm{L}$ & C. typicus: NI-NII, NIV-NV, CVI & Titelman \& Kiørboe (2003) \\
\hline & Sensitivity threshold $\left(\mathrm{s}^{-1}\right)$ & $0.396 \times \mathrm{L}^{-1}$ & C. typicus: NI-NII, NIV-NV, CVI & Titelman \& Kiørboe (2003) \\
\hline & Escape jump angle (rad) & 0.421 & C. typicus: NI-NII, NIV-NV, CVI & Titelman \& Kiørboe (2003) \\
\hline
\end{tabular}



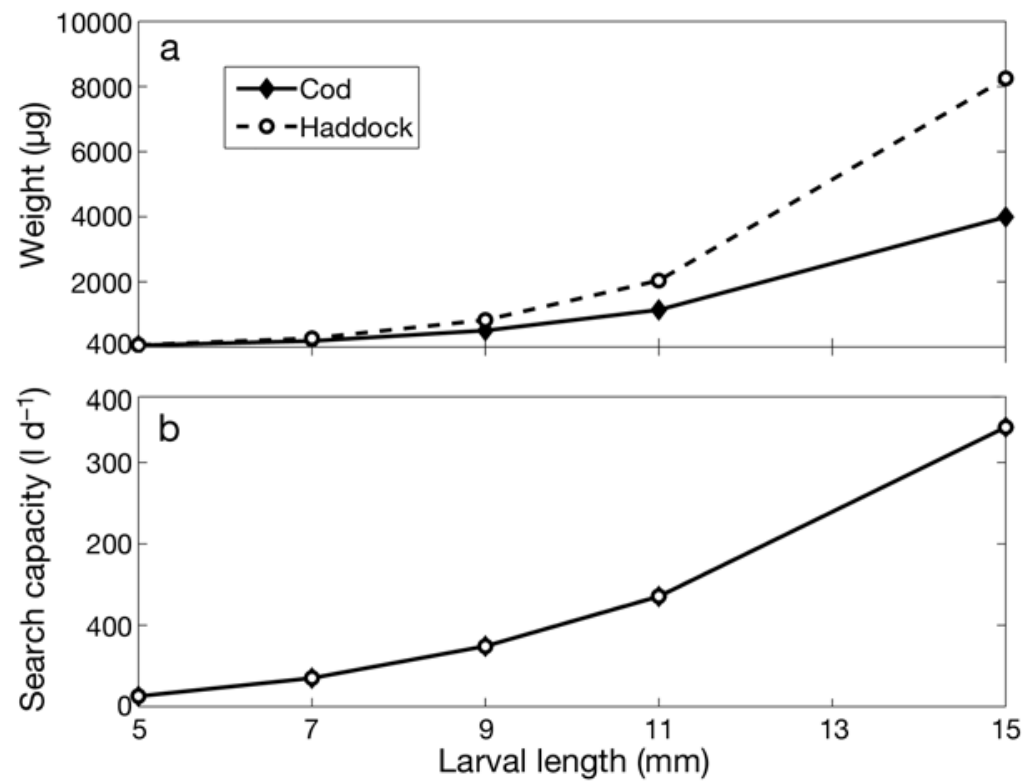

Fig. 1. Melanogrammus aeglefinus and Gadus morhua. (a) Dry body mass of larvae as a function of length as determined by the species-specific equations in Laurence (1985). (b) Search capacity of larvae as a function of length. Note that the lines in (b) are overlapping. Weight for both species was calculated from length (a), and then search capacity was calculated from weight. Both calculations used the species-specific equations of Laurence (1985)

ment (Ivlev 1961). Active prey selection occurs when a predator actively selects and rejects prey, possibly for taste or nutritional value, while fixed prey selection occurs because some prey types are more vulnerable than others (Greene et al. 1986). Chesson's preference index, $\alpha_{i}$ detects prey selection by measuring preference for a specific prey type relative to its abundance and the abundance of the other prey types (Chesson 1978). It is calculated as

$$
\alpha_{i}=\frac{\left(r_{i} / n_{i}\right)}{\sum_{i=1}^{m}\left(r_{i} / n_{i}\right)}
$$

where $r_{i}$ is the number of prey type $i$ in the diet, $n_{i}$ is the abundance of prey type $i$ in the environment, and $m$ is the total number of prey types. Neutral selection occurs when prey types are eaten in amounts proportional to their abundance in the environment $(1 / m)$. A preference value above neutral indicates positive selection, whereas a value below specifies negative selection (Chesson 1978). Chesson's preference index was also used to calculate

lationship derived for haddock and a routine respiration rate as a function of weight and temperature calculated for haddock by Lankin et al. (2008; our Eq. 4). PF and PD were the only behavioral characteristics varied between simulations (Table 2). The first baseline simulation used $\mathrm{PF}$ and $\mathrm{PD}$ values employed for larval cod $>5.5 \mathrm{~mm}$ by Lough et al. (2005), PF $=0.53 \mathrm{~s}^{-1}$ and $\mathrm{PD}=1.4 \mathrm{~s}$. The second and third simulations respectively used $\mathrm{PF}$ values $200 \%$ and $50 \%$ of those for cod. According to Ruzicka \& Gallager (2006b) the BD of larval cod is relatively constant across different environmental conditions, but PF and PD are plastic. PF and PD are inversely related, such that if one is increased the other must decrease so that $\mathrm{BD}+\mathrm{PD}=\mathrm{PF}^{-1}$ (Ruzicka 2004). This formulation was used to calculate the PD for the second and third simulations assuming that BD for haddock is equal to that of cod. PF was chosen as the behavior to alter because it has a greater effect in the encounter rate model. We looked at the effects of foraging behavior parameters on average biomass and prey length ingested and Chesson's preference index. Percent error was calculated between observations and each simulation (model-data misfit). Percent difference of the $200 \%$ and $50 \%$ simulations from the baseline haddock model were also calculated.

Prey preference index. Prey selection is defined as a difference between the composition of a predator's diet and the availability of prey types in the environ- ratios of preferred prey length to larval length, and preferred prey width to larval length.

Simulation experiments. A total of 40 simulations were run: 5 initial larval lengths $(5,7,9,11$, and $15 \mathrm{~mm}), 2$ yr (1993, 1994), 2 species (cod, haddock), and 3 different parameterizations for haddock (50, 100 , and $200 \%$ PF). The larvae were initialized at different lengths to compare their foraging and growth results to observations of 3 to $5 \mathrm{~mm}, 6$ to $8 \mathrm{~mm}$, and 9 to $13 \mathrm{~mm}$ larvae (Lough et al. 2005, Broughton \& Lough in press). Both haddock and cod were simulated in order to compare and contrast their prey preferences. Due to the uncertainty of haddock foraging behavior, 3 different parameterizations of PF and PD were completed to examine their effect on prey preference and growth.

Table 2. Melanogrammus aeglefinus. Saltatory foraging behavior parameters and values used for haddock simulations. PF: pause frequency; PD: pause duration

\begin{tabular}{|lcc|}
\hline \multirow{2}{*}{ Parameter } & \multicolumn{2}{c|}{ Value used for simulation } \\
& PF $\left(\mathrm{s}^{-1}\right)$ & PD (s) \\
\hline Baseline $^{\mathrm{a}}$ & 0.53 & 1.40 \\
$200 \%$ of baseline PF value & 1.06 & 0.457 \\
$50 \%$ of baseline PF value & 0.265 & 3.287 \\
${ }^{\text {a From Lough et al. (2005) }}$ & & \\
\hline
\end{tabular}




\section{RESULTS}

\section{Copepod escape parameters}

The accuracy of the copepod behavior functions was assessed by comparing them to observations. Viitasalo et al. (2001) observed that adult Pseudocalanus spp. had a lower deformation rate threshold compared to adult Temora longicornis. From our equations, the detection threshold of an adult Pseudocalanus is $2.8 \mathrm{~s}^{-1}$, which is less than the $6.5 \mathrm{~s}^{-1}$ calculated for an adult $T$. longicornis (Kiørboe et al. 1999). Other sources of agreement between the equations and observations include the Calanus finmarchicus deformation threshold being much less than that of Oithona similis (Kiørboe et al. 1999), and that nauplii of any particular species need larger deformation rates than copepodites of that same species (Titelman 2001). Titelman \& Kiørboe (2003) used a model to calculate which type of swimming style would result in the greatest encounter rates with larval cod. When all else was held constant, encounter rate decreased in the order of the following styles: high-frequency hopsink, medium-frequency hop-sink, continuously cruising in straight lines, continuously cruising in loops, and low-frequency hopsink. By using our equations for swimming speed to estimate encounter rate for hypothetical copepods of the same size, encounter would be greatest for C. finmarchicus, followed by Centropages typicus, then Pseudocalanus spp., and lastly $O$. similis. Since the motility of $C$. finmarchicus and C. typicus is medium-frequency hopsink, Pseudocalanus spp. is a continuous swimmer, and $O$. similis has a low-frequency hop-sink motility (Mauchline 1998, Titelman \& Kiørboe 2003), our results agree with those of Titelman \& Kiørboe (2003).

Escape angle (where $0^{\circ} / 180^{\circ}$ is directly away from/towards the predator) increased with Centropages typicus, Pseudocalanus spp. and Oithona similis, and lastly, Calanus finmarchicus (Fig. 2a). O. similis had the slowest swimming speed, followed by Pseudocalanus spp., C. typicus, and C. finmarchicus (Fig. 2b). C. finmarchicus was the fastest at escape jumping, with C. typicus, Pseudocalanus spp., and $O$. similis slower (Fig. 2c). Of the 4 main prey targets, the most sensitive (lowest deformation rate threshold) was $C$. typicus, then $C$. finmarchicus, with the much less sensitive Pseudocalanus spp. and $O$. similis following (Fig. 2d).

\section{Modeled haddock feeding on observed prey densities}

At prey densities observed in May of 1993 and 1994 on Georges Bank, larval haddock had the greatest probability of capturing Oithona similis, followed by Pseudocalanus spp., Centropages typicus, and Calanus finmarchicus in decreasing order (e.g. see 5 and 9 mm cases for 1993 in Fig. 3a,b). The probabil-

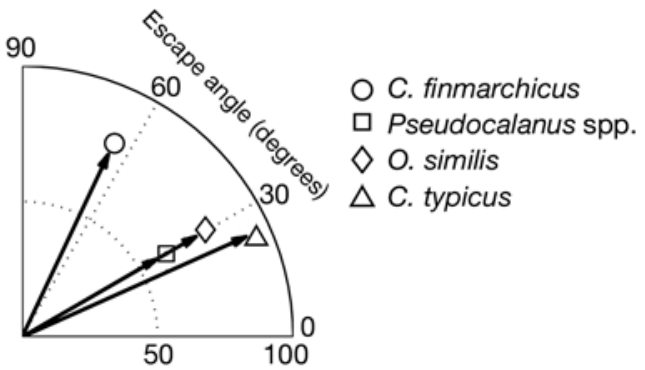

a
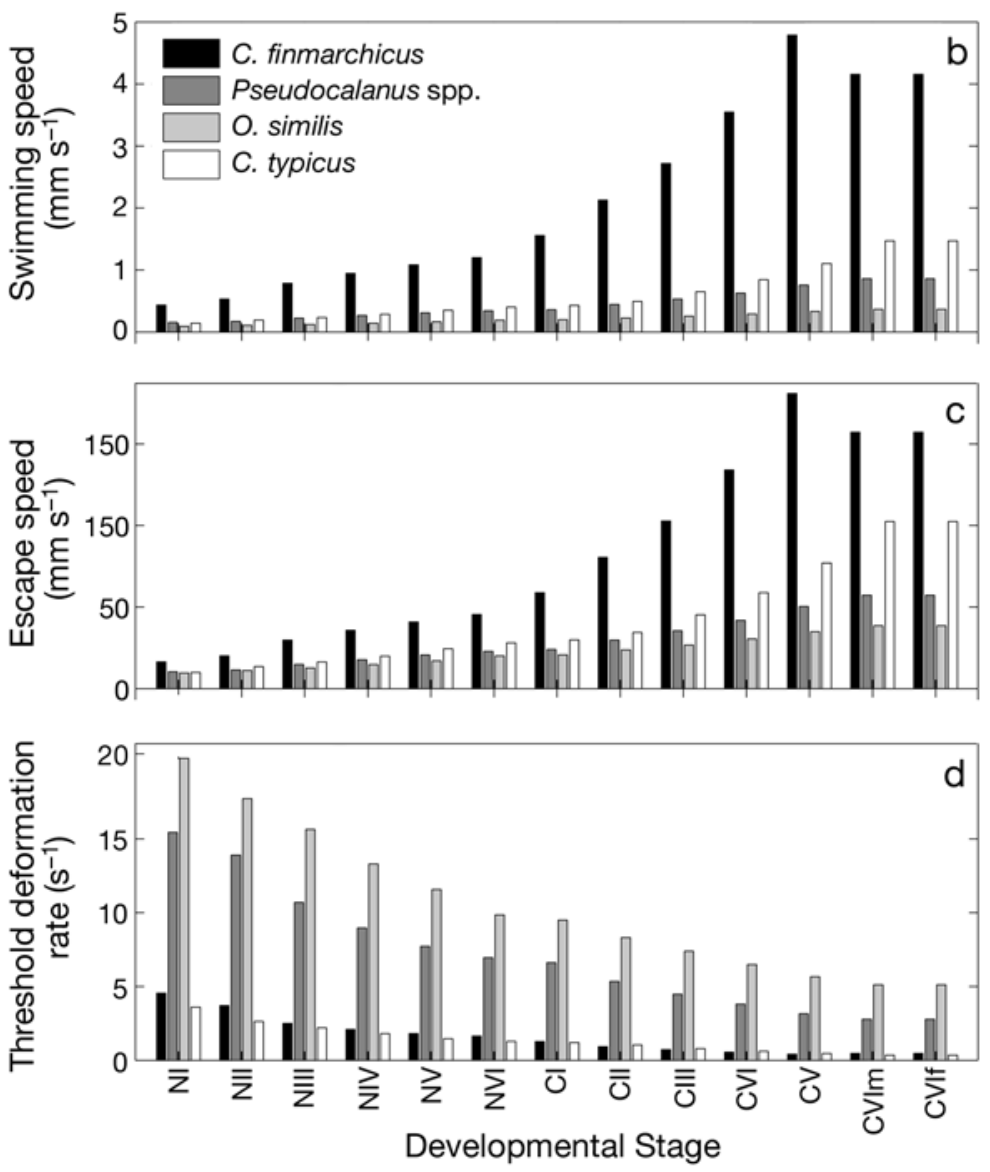

Fig. 2. Calanus finmarchicus, Pseudocalanus spp., Oithona similis, and Centropages typicus. Parameterized (a) escape jump angle and speed for each species, (b) swimming speed, (c) escape jump speed, and (d) deformation rate threshold of each developmental stage. BL: body length, NI to NVI: 6 naupliar stages, CI to CV: 5 copepodite stages, CVIf: adult female, CVIm: adult male 
ity of capturing a given copepod stage increased with larval size (cf. Fig. 3a,b). Chesson's preference index for all sizes in both years revealed a strong preference for Pseudocalanus spp. (e.g. 1993, Fig. 3c,d). Some stages of $O$. similis and $C$. typicus were positively selected, while others negatively (cf. Fig. 3c,d). Larval haddock under $15 \mathrm{~mm}$ in length had a negative selection for all stages of C. finmarchicus (Fig. 3c,d). In both years, haddock increasingly preferred larger, later stages as the larva grew (e.g. 1993, Fig. 3c,d). As larval size increased, preference for $C$. finmarchicus and
C. typicus increased, O. similis preference decreased, and preference for Pseudocalanus spp. varied little with haddock length (Table 3). On average, modeled larval haddock preferred in decreasing order: Pseudocalanus spp., C. typicus, O. similis, and C. finmarchicus (Table 3). Using prey densities from 1994 resulted in a decrease in preference for Pseudocalanus spp. and C. typicus, and an increase in preference for C. finmarchicus and O. similis (Table 3) compared to 1993.

The ratio of preferred prey length to larval length was between 0.03 and 0.13 for both 5 and $9 \mathrm{~mm}$ larval
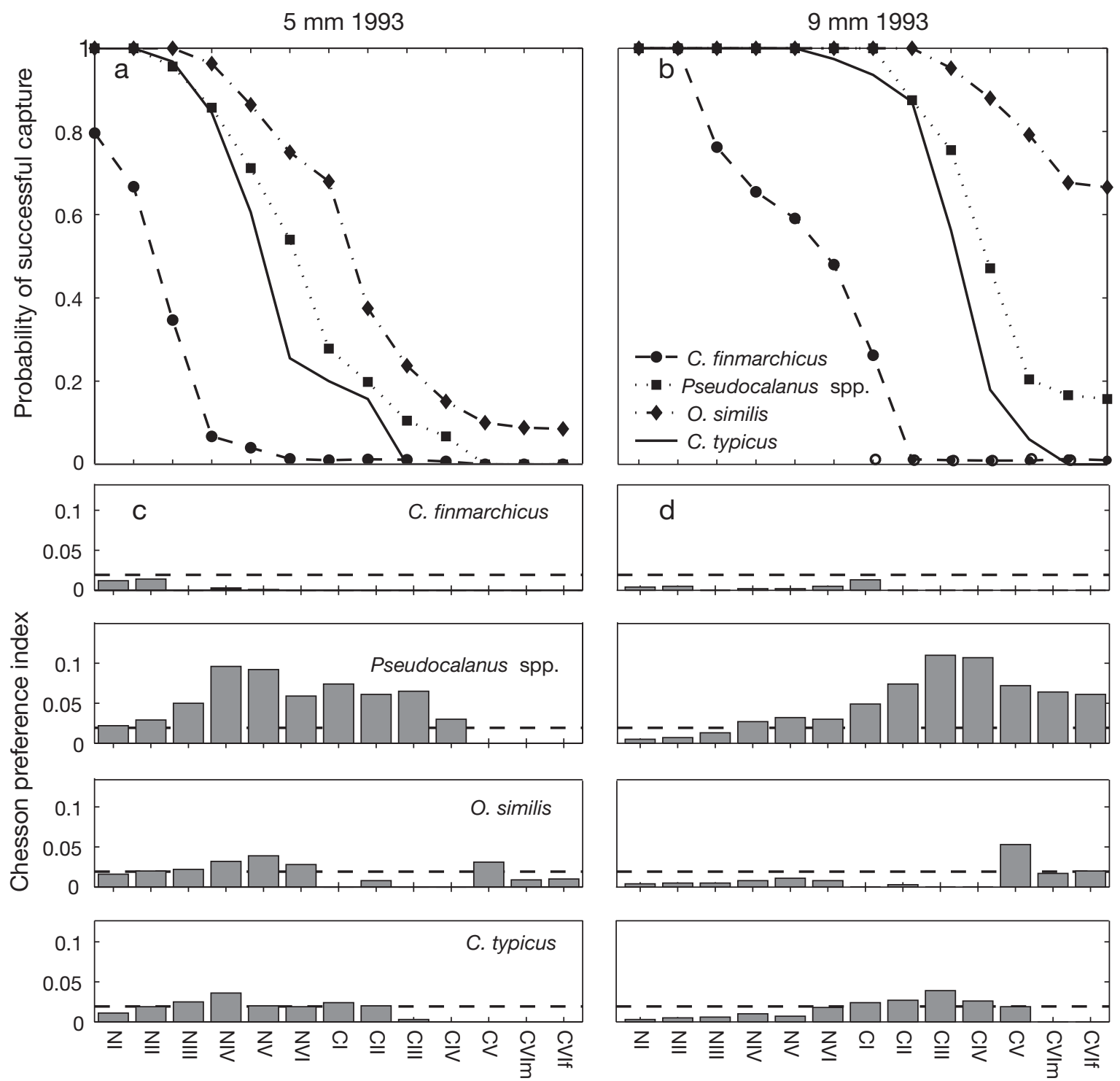

\section{Developmental stage}

Fig. 3. Melanogrammus aeglefinus. Modeled probability of successful capture for (a) $5 \mathrm{~mm}$ and (b) 9 mm larvae. Modeled Chesson's preference index for each developmental stage of Calanus finmarchicus, Pseudocalanus spp., Oithona similis, and Centropages typicus feeding on observed copepod densities from 1993 for (c) $5 \mathrm{~mm}$ and (d) $9 \mathrm{~mm}$ larvae. The dashed line indicates neutral selection, $\alpha=0.019$. NI to NVI: 6 naupliar stages, CI to CV: 5 copepodite stages, CVIf: adult female, CVIm: adult male 
Table 3. Melanogrammus aeglefinus. Sum of modeled larval haddock Chesson's preference index $(\times 100)$ of all developmental stages of each copepod species. Neutral selection $\alpha=25$

\begin{tabular}{|lcccccc|}
\hline & \multicolumn{7}{c|}{ Chesson's preference index $(\times 100)$} & \\
\cline { 2 - 7 } Copepod species & 5 & 7 & 9 & 11 & 15 & Mean \\
\cline { 2 - 7 } & & & & & & \\
\hline $\mathbf{1 9 9 3}$ & 3.0 & 2.8 & 3.1 & 4.4 & 8.2 & 4.3 \\
Calanus finmarchicus & 57.8 & 65.8 & 65.1 & 65.1 & 60.9 & 62.9 \\
Pseudocalanus spp. & 21.5 & 12.9 & 13.4 & 11.0 & 7.0 & 13.2 \\
Oithona similis & 17.7 & 18.4 & 18.4 & 19.5 & 24.0 & 19.6 \\
Centropages typicus & & & & & & \\
1994 & 2.9 & 5.4 & 4.9 & 5.1 & 8.7 & 5.4 \\
Calanus finmarchicus & 57.0 & 59.6 & 59.1 & 60.2 & 59.1 & 59.0 \\
Pseudocalanus spp. & 23.0 & 18.5 & 19.1 & 16.3 & 11.0 & 17.6 \\
Oithoma similis & 17.1 & 16.6 & 16.8 & 18.5 & 21.4 & 18.1 \\
Centropages typicus & 17.6 & \\
\hline
\end{tabular}

haddock (Fig. 4a,b). The ratio of preferred prey width to larval length was wider for $5 \mathrm{~mm}$ larvae $(0.02$ to 0.08; Fig. 4c) than for $9 \mathrm{~mm}$ larvae $(0.015$ to 0.045 ; Fig. 4d). However, the strength of preference for all copepod stages of the same length and/or width was not the same, with Pseudocalanus spp. being the highest (Fig. 4). The same results were obtained for the 1994 runs (data not shown), thus, simulated haddock larvae preferred prey with the same length to larval length ratio in both years. The average prey length eaten in 1994, however, was greater than in 1993 for the 7, 9, and $11 \mathrm{~mm}$ size classes (Fig. 5a). The average biomass ingested increased with larval size and was greater in 1994 than 1993 for all sizes (Fig. 5b). The average growth rate $\left(\% \mathrm{~d}^{-1}\right)$ increased until $11 \mathrm{~mm}$ and then declined for $15 \mathrm{~mm}$ haddock larvae (Fig. 5c). Growth rates were also higher in 1994 than 1993 for all sizes of larval haddock (Fig. 5c) and all depths above $65 \mathrm{~m}$ (Fig. 5d). Growth was negative at depths below $55 \mathrm{~m}$ (Fig. 5d).

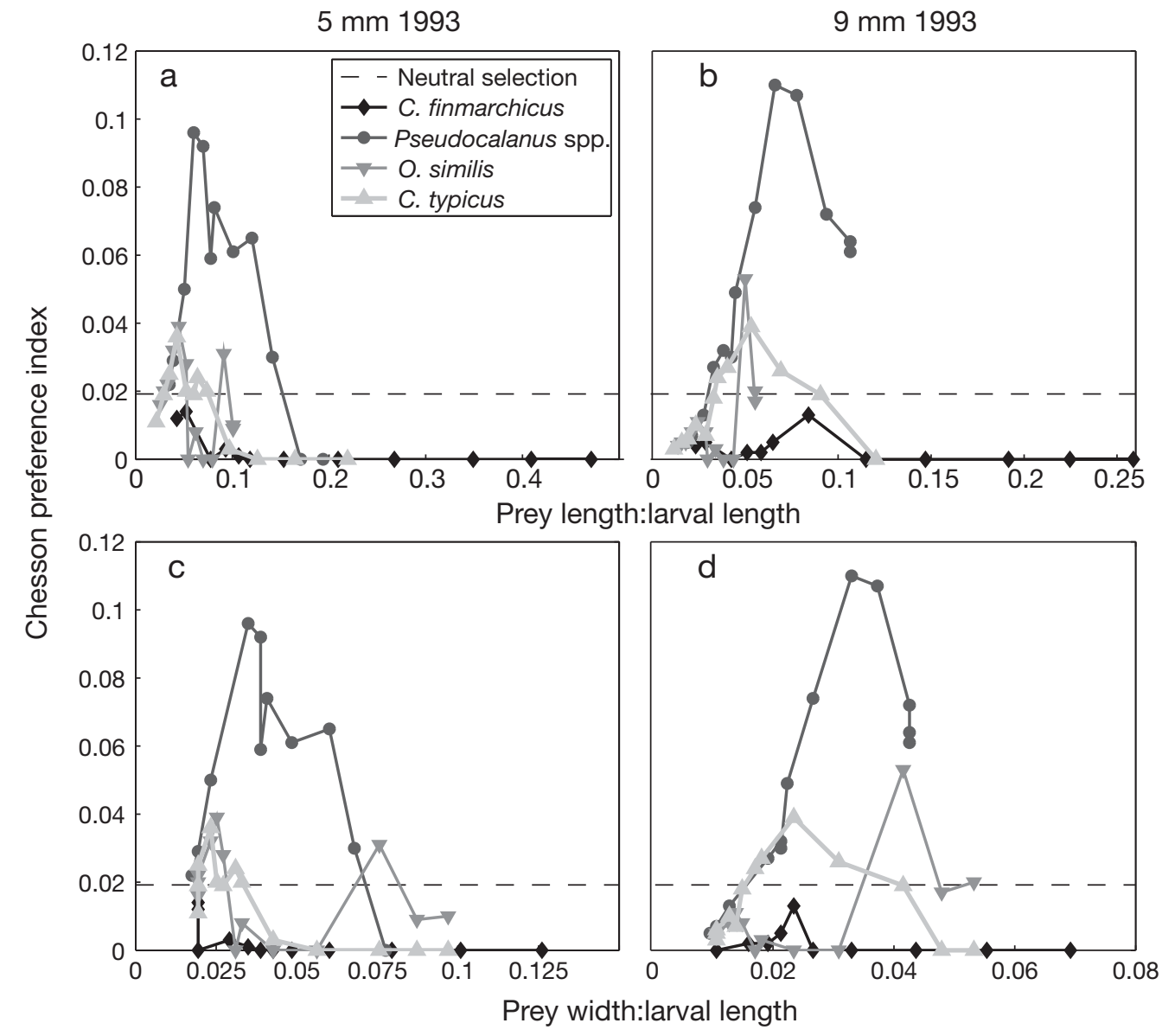

Fig. 4. Melanogrammus aeglefinus. Modeled preference as a function of prey length:larval length ratio (a,b) and prey width: larval length ratio (c,d) for Calanus finmarchicus, Pseudocalanus spp., Oithona similis, and Centropages typicus with prey densities observed in 1993 for $(\mathrm{a}, \mathrm{c}) 5 \mathrm{~mm}$ and $(\mathrm{b}, \mathrm{d}) 9 \mathrm{~mm}$ larvae 


\section{Comparisons between modeled haddock and cod}

The qualitative differences between simulations for cod using observed prey distributions from 1993 and 1994 were the same as those for haddock. The probability of cod capturing a given copepod species followed the same decreasing order as found for haddock: Oithona similis, Pseudocalanus spp., Centropages typicus, and Calanus finmarchicus. At $5 \mathrm{~mm}$, the probability of capturing each stage was greater for haddock (Fig. 6a). At $7 \mathrm{~mm}$ the probabilities of capture were very similar, with cod slightly greater than haddock for the stages where they differed (data not shown). Larger cod (9 to $15 \mathrm{~mm}$ ) had a greater probability of successful capture of all copepod species and stages (Fig. 6b-d).

Under observed prey conditions, the differences in Chesson's preference index between haddock and cod appeared small under both 1993 and 1994 conditions (cf. 1993 in Fig. 7), with nearly identical preferences in both years. Nonetheless, for prey densities observed in 1993 and 1994, $5 \mathrm{~mm}$ haddock ate on average larger prey than cod, while cod in the 9 to $15 \mathrm{~mm}$ length classes ate larger prey than haddock (Fig. 8a,b). On average, haddock larvae consumed a greater biomass of copepods than cod for all sizes and years (Fig. 8c,d). Average daily growth rates were greater for $5 \mathrm{~mm}$ haddock larvae, equivalent for $7 \mathrm{~mm}$ larvae, and greater for 9 to $15 \mathrm{~mm}$ cod larvae as modeled for both years (Fig. 8e,f). By depth, the growth rates were similar in 1993 (Fig. 8g), with cod growth rates greater in the surface and deep waters. In 1994, cod growth exceeded that of haddock at all depths (Fig. 8h).

\section{Comparisons to observations}

Observations of larval haddock and cod gut contents as well as measurements of RNA:DNA ratios were made on the same cruise that measured the prey distribution used to force the model (Lough et al. 2005). Modeled foraging results were compared to observed gut contents and the resulting Chesson's preference index (Broughton \& Lough in press), while growth rates were compared to those calculated from the RNA:DNA ratios and reported by Lough et al. $(1997,2005)$.

The observed prey composition in the gut did not differ between each corresponding size class (3 to $5 \mathrm{~mm}$, 6 to $8 \mathrm{~mm}$, and 9 to $13 \mathrm{~mm}$ ) of larval haddock and cod for both 1993 and 1994 ( $\chi^{2}$ test, $p>0.05$ ). The absence of statistically significant differences in gut contents, as well as significant niche overlap (Broughton \& Lough in press), are reflected in the nearly identical modeled preferences of haddock and cod (Fig. 7). The model was able to capture some qualitative differences, such as haddock eating smaller prey than cod (Fig. 8a,b) and haddock eating younger stages of copepods for longer than cod. Broughton \& Lough (in press) found that in 1994 cod larvae shifted to larger, later-stage copepods sooner than haddock larvae. A similar trend can be seen in the modeled Chesson's preference index grouped by stage, where 7 and $9 \mathrm{~mm}$ cod had greater preference for Pseudocalanus spp. adults and the larger copepodite stages of all species, while haddock showed stronger preference for the smaller
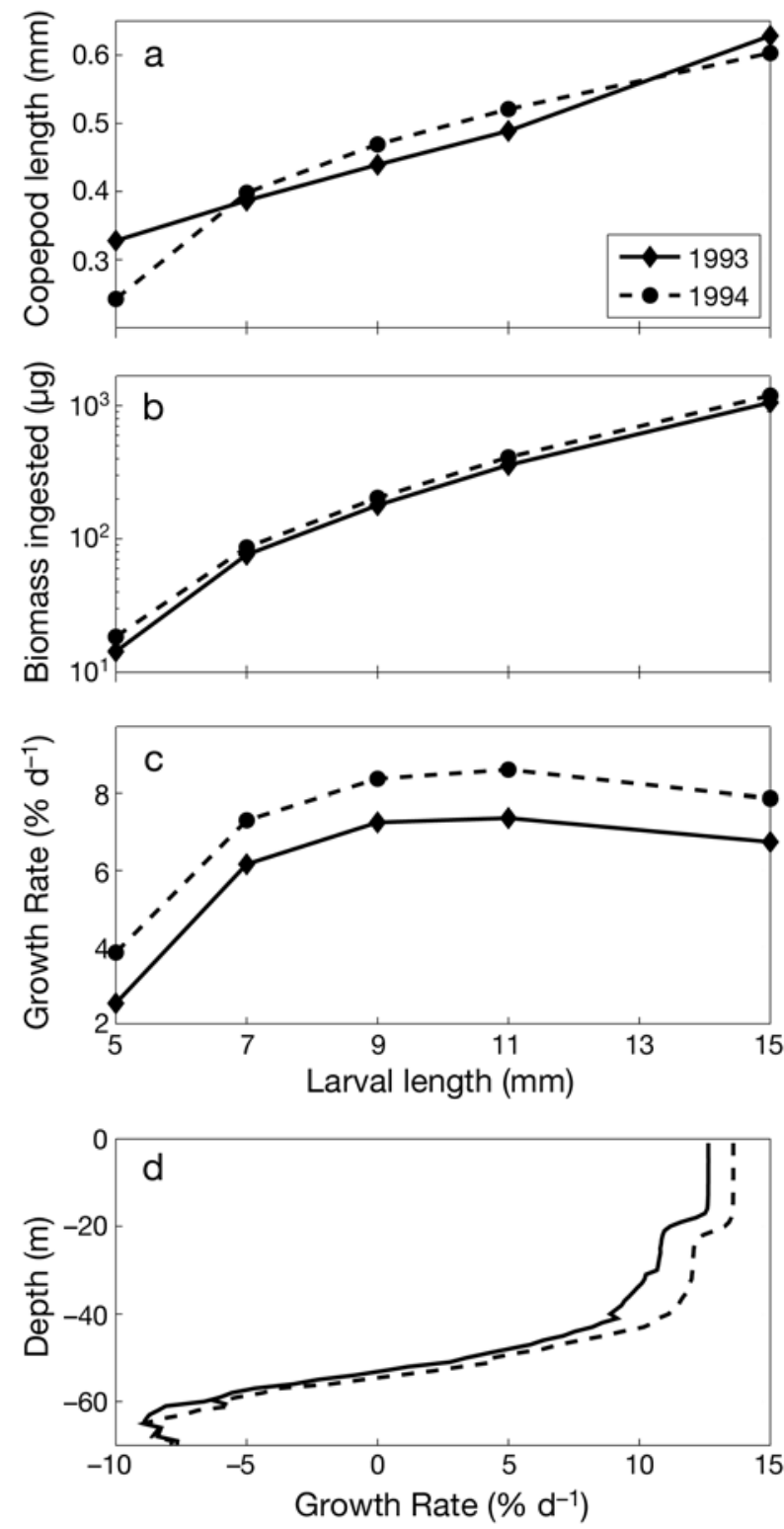

Fig. 5. Melanogrammus aeglefinus. Modeled (a) average length of prey eaten by each size class, (b) average copepod biomass (dry wt) ingested daily by each size class, and average daily growth rate by (c) size and (d) depth, for simulations under observed prey conditions from 1993 (solid line) and 1994 (dashed line) 
Oithona similis, Pseudocalanus spp., and Centropages typicus nauplii (Fig. 9).

Broughton \& Lough (in press) established that Chesson's preference indices of haddock and cod demonstrate positive selection for all life stages of Pseudocalanus spp. and varying life stages of Oithona similis, which agrees with model results. To perform a statistical comparison, Chesson's preference index was calculated from the modeled individuals in the 10 observed MOCNESS depth bins (midpoints of surface, $5,15,25,30,35,45,50,55$, and $60 \mathrm{~m}$ ). The index for each depth bin was then weighted by the number of individual larvae observed in that depth bin. These values were averaged to produce an index weighted by depth for each of the 52 prey types. The observed Chesson's preference index was given for a group of stages (Calanus finmarchicus: NI to NIII, NIV to NVI, CI to CII, CIII to CIV, CV to CVI; Pseudocalanus spp., Oithoma similis, and Centropages typicus: NI to NIII, NIV to NVI, CI to CIII, CIV to CV, CVI), thus modeled indices for the stages within a group were added together to create 1 index for each group. This was done for each of the $5,7,9$, and $11 \mathrm{~mm}$ size classes.

A Kendall rank correlation analysis was performed to assess agreement between the observed and depthweighted modeled preference indices. The correlation coefficients demonstrate weak to moderate agreement (Table 4). Independence was rejected in 7 out of 16 cases with $\mathrm{p}<0.05$ and 12 cases with $\mathrm{p}<0.1$ (Table 5), suggesting that the model was capturing aspects of the observations.
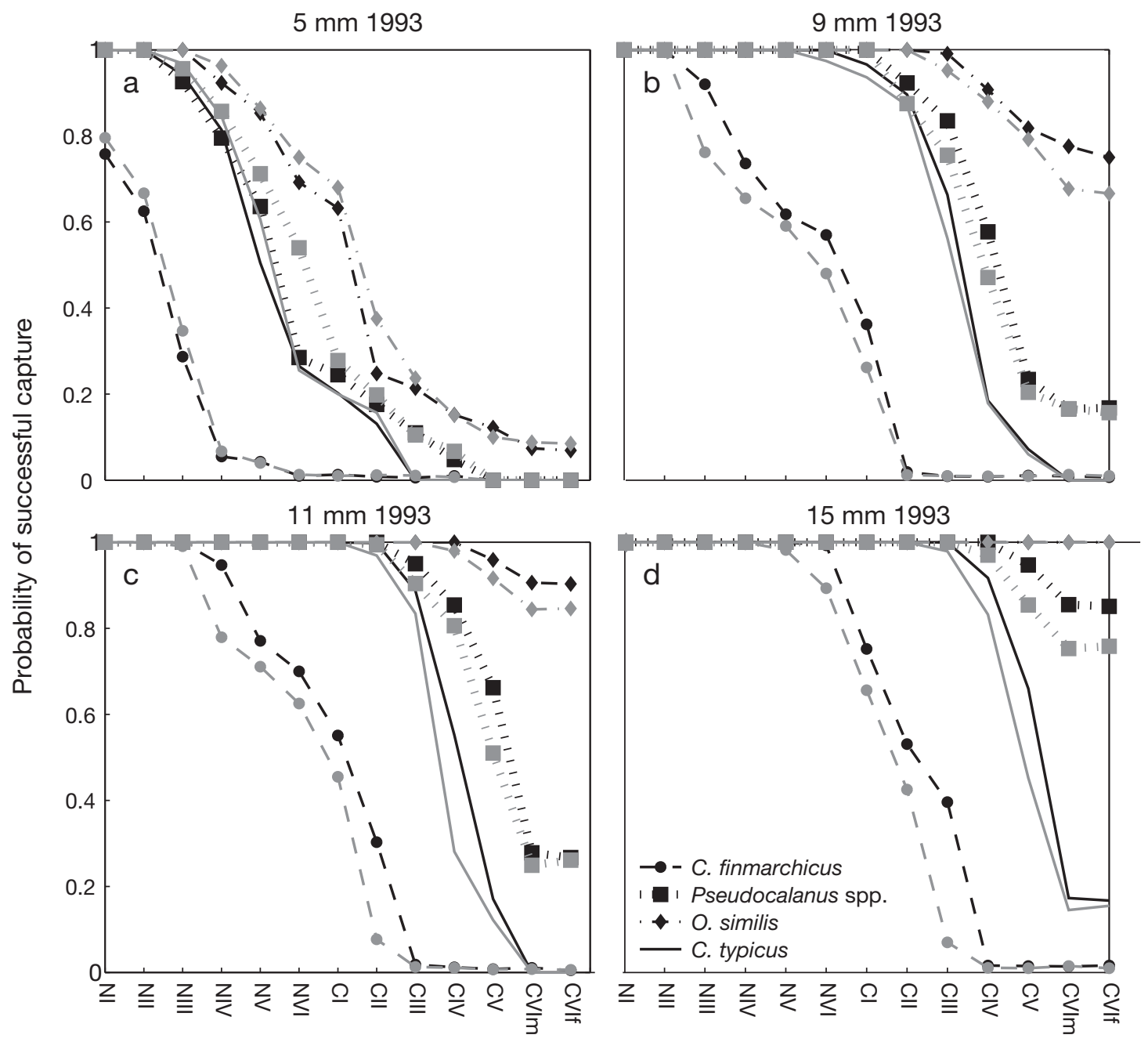

Developmental stage

Fig. 6. Melanogrammus aeglefinus (gray) and Gadus morhua (black). Differences in modeled probability of successful capture for each developmental stage of Calanus finmarchicus, Pseudocalanus spp., Oithona similis, and Centropages typicus under 1993 observed prey conditions for larvae of size (a) $5 \mathrm{~mm}$, (b) $9 \mathrm{~mm}$, (c) $11 \mathrm{~mm}$, and (d) $15 \mathrm{~mm}$. NI to NVI: 6 naupliar stages, CI to CV: 5 copepodite stages, CVIf: adult female, CVIm: adult male 
The lengths of copepods eaten by larval haddock and cod do not differ significantly (Wilcoxon rank-sum test, $\mathrm{p}>0.05$ ) with the exception of the $5 \mathrm{~mm}$ length class in 1994 (Wilcoxon rank-sum test, p = 0.02). Contrary to model results (Fig. 8b), field-caught cod larvae of 3 to $5 \mathrm{~mm}$ ate larger prey than haddock larvae in 1994. From observations of 5 to $11 \mathrm{~mm}$ haddock and cod, the average length of copepods eaten predicted by the model fell within $1 \mathrm{SD}$ for haddock 5 to $9 \mathrm{~mm}$ in 1993 and 5 to $11 \mathrm{~mm}$ in 1994, and for cod 5 to $11 \mathrm{~mm}$ in 1993 and 5 to $9 \mathrm{~mm}$ in 1994 (Fig. 10). The model had a tendency to underestimate the average length eaten by the larger larvae.

There was no statistical difference between the observed amount of biomass ingested by haddock and cod larvae (Wilcoxon rank-sum test, p > 0.05), again with the exception of the $5 \mathrm{~mm}$ size class in 1994, where cod ate significantly more biomass than haddock (Wilcoxon rank-sum test, $\mathrm{p}=0.02$ ). This one difference is not reflected in the model; $5 \mathrm{~mm}$ haddock and cod ate roughly the same amount of biomass in 1994 (0.75 and $0.73 \mu \mathrm{g}$ respectively; Fig. 8d). The amount of biomass found in the guts of field-caught larvae was greater than that simulated by the models for haddock and cod of all sizes and years. With the exception of $11 \mathrm{~mm}$ haddock in 1993, biomass estimates were within $1 \mathrm{SD}$ of observed values (Fig. 11a-d). Haddock and cod ingested more biomass in 1994 than 1993 for all sizes of larvae in simulations (Figs. 5b \& 8c,d), whereas observed $11 \mathrm{~mm}$ haddock and $9 \mathrm{~mm}$ cod larvae did not (Fig. 11e,f).

Finally, model growth rates were compared to those measured from field-collected larval haddock (Lough et al. 1997) and cod (Lough et al. 2005) from the May 1993

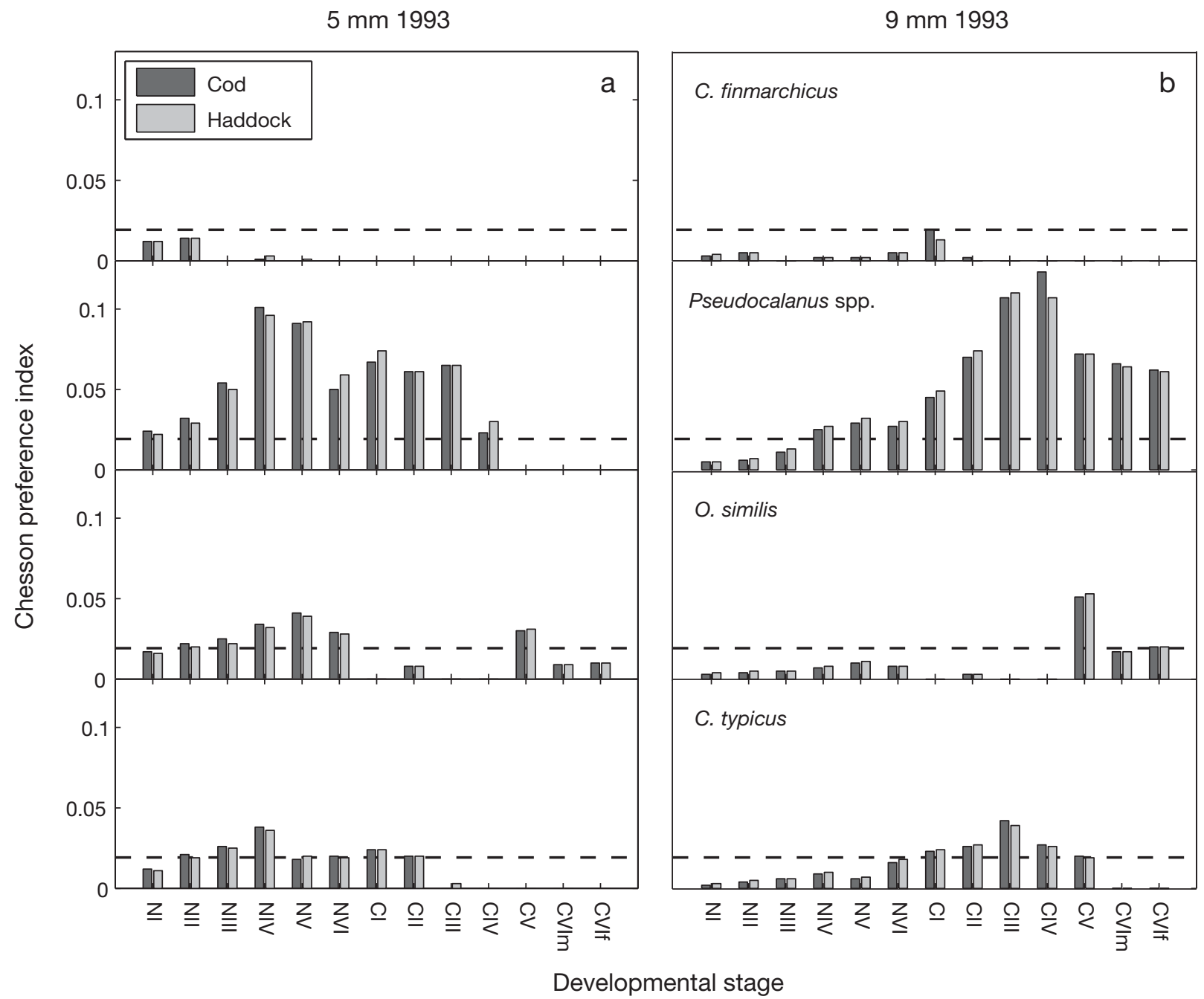

Fig. 7. Melanogrammus aeglefinus (light grey bar) and Gadus morhua (dark grey bar). Simulations of Chesson's preference index of Calanus finmarchicus, Pseudocalanus spp., Oithona similis, and Centropages typicus for (a) $5 \mathrm{~mm}$ and (b) 9 mm larvae forced by 1993 environmental conditions. The dashed line $(\alpha=0.019)$ indicates neutral selection. NI to NVI: 6 naupliar stages, CI to CV: 5 copepodite stages, CVIf: adult female, CVIm: adult male 
and 1994 Georges Bank study. Mean growth rates of modeled $5 \mathrm{~mm}$ haddock and cod larvae were much less than those observed (Tables $6 \& 7$ ). The $7 \mathrm{~mm}$ cod larvae from both the 1993 and 1994 simulations were within 2 SDs, while $9 \mathrm{~mm}$ cod larvae in simulations of 1994 were within 1 SD of observations (Table 7). Since individual larvae were constrained to $1 \mathrm{~m}$ depth intervals, modeled growth rates were not expected to quantitatively match observed growth rates.

\section{Changes to foraging behavior parameters}

Differences in the average prey length eaten and Chesson's preference index between the haddock simulations with different PF and PD values were minor. There was a 1 to $3 \%$ difference in average length of copepods ingested between models, a difference that was 10 to 20 times smaller than the SD of the observations. The percent error ranged from 0 to 32 , with all simulations being within $1 \mathrm{SD}$ of the observations for 5 to $9 \mathrm{~mm}$ length classes. Chesson's preference index was also similar between simulations with differing PF and PD values. Simulations differed from each other by 0 to $14 \%$ and from observations by 0 to $1300 \%$. When a particular simulation decreased the percent error for one group of stages of a copepod species, it increased in error for another group. The small differences between simulations were also reflected in the Kendall rank correlation analysis with the observed Chesson's preference index, with 0 to $11 \%$ difference between them. An increase in correlation of a small length class often led to a decrease in correlation of a larger length class for the same parameterization.

\section{DISCUSSION}

The ability of a fish and its prey to react to their surroundings by explicit behavior is a key element in understanding the feeding ecology of fish. Behavior of fish has often been neglected, or simply been defined as a static pattern in IBMs; however, several recent papers have pointed to the importance of including behavior in the growth, survival, and drift patterns of ichthyoplankton (Fiksen et al. 2007, Kristiansen et al. 2007, 2009a, Leis 2007, Vikebø et al. 2007). Here, we have shown how differences in behavior among copepod prey species largely determine the feeding preference of both larval haddock and cod, and it is clear that prey selection cannot be predicted by prey length or width alone.

The addition of species-specific copepod escape behavior elucidated the dif-
Fig. 8. Melanogrammus aeglefinus (dashed line) and Gadus morhua (solid line). Modeled average length of prey eaten in (a) 1993 and (b) 1994. Modeled average copepod biomass (dry wt) ingested daily by each size class of larvae under observed (c) 1993 and (d) 1994 prey densities. Modeled average daily growth rate by $(e, f)$ size and $(g, h)$ depth with $(e, g) 1993$ and $(f, h) 1994$ copepod concentrations 
ferences in encounter and capture probability of the 4 dominant prey items of larval haddock and cod on Georges Bank. Swimming speed affects the encounter rate between a copepod and a predator, thus fast swimming prey will encounter predators more often. The deformation rate threshold indicates how sensitive a copepod is to disturbances, which helps it detect and escape predators. A lower threshold signifies greater sensitivity. Of the 4 main prey targets the order of sensitivity was exactly the same as for swimming speed, suggesting that those copepods that encounter predators more often must be more sensitive to detecting

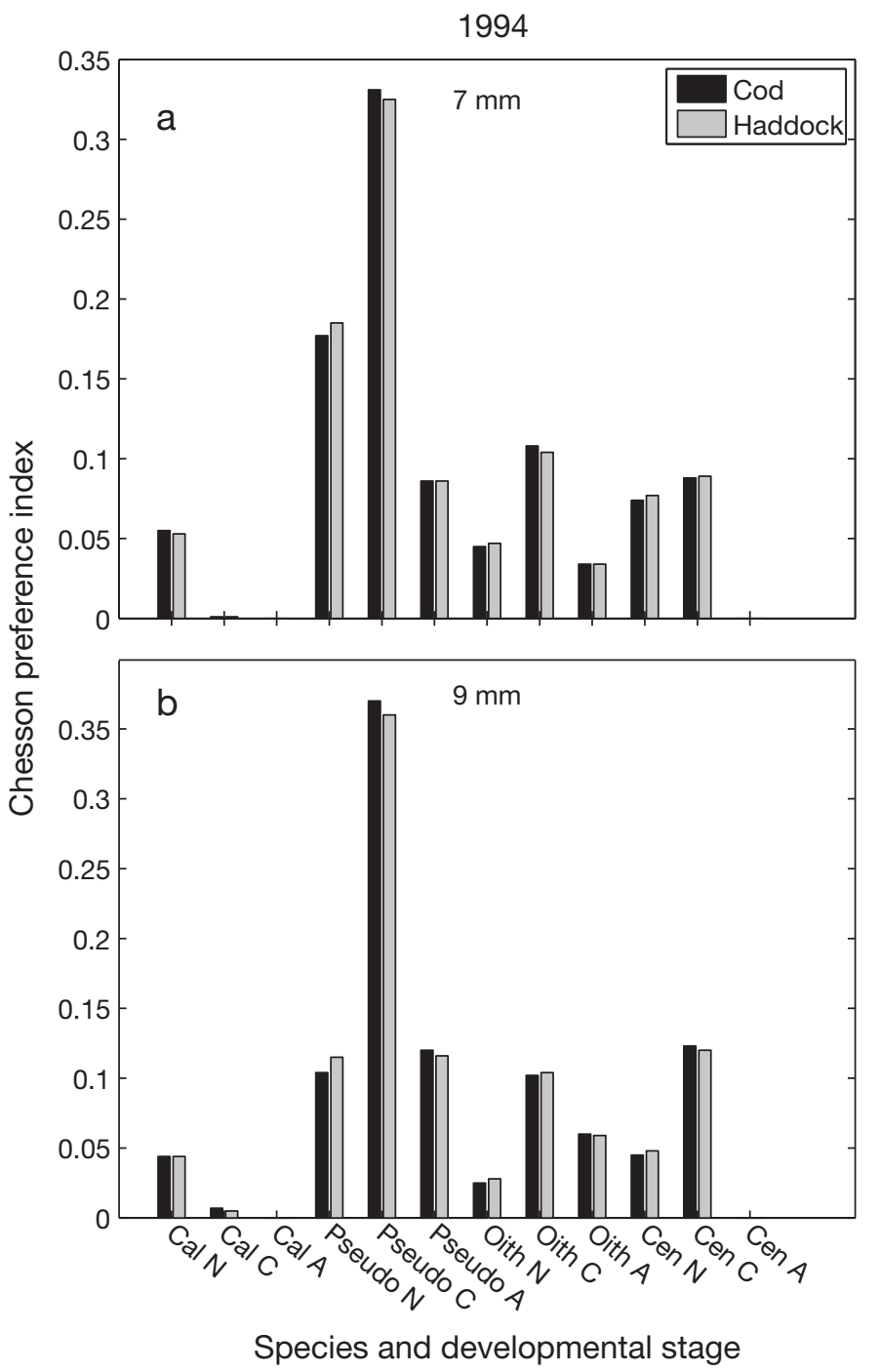

Fig. 9. Melanogrammus aeglefinus (grey bar) and Gadus morhua (black bar). Modeled Chesson's preference index grouped by species (Cal: Calanus finmarchicus, Pseudo: Pseudocalanus spp., Oith: Oithona similis, Cen: Centropages typicus) and stage (N: nauplii, C: copepodites, A: adults) for (a) $7 \mathrm{~mm}$ and (b) $9 \mathrm{~mm}$ larvae simulated under prey conditions from 1994 them. The vulnerability of each copepod species and stage is a function of its visibility and catchability, and can be inferred from its size, its escape behavior, and measures of larval fish gut contents and preference.

With species-specific prey behavior the model was able to reproduce the lower preference for Centropages typicus. The probability of capture results indicate that both infrequent encounter rates from small image area and slow swimming speed, and low probability of capture from a sensitive deformation threshold and fast escape jump speed contribute to the reduced vulnerability and negative selection of C. typicus by larval haddock and cod. Oithona similis and Pseudocalanus spp. are the easiest to catch because of their high deformation rate thresholds, slow escape jump speeds, and, for O. similis, its small size. Though their small size and slow swimming speeds do not lead to frequent encounters, their high abundance and ease of capture results in positive selection for them and thus they make up a large portion of the diet numerically. Calanus finmarchicus is encountered often because of its large image area and fast swimming speed, but it is difficult to capture because it has a very low deformation rate threshold and a fast escape jump speed, and many stages are too wide to be engulfed by the larval fish. For haddock and cod, the small probability of capture outweighed the high encounter rate such that $C$. finmarchicus was negatively selected.

Table 4. Melanogrammus aeglefinus and Gadus morhua. Kendall rank correlation coefficients between observed and depth-weighted modeled Chesson's preference index

\begin{tabular}{|lcccc|}
\hline \multirow{2}{*}{$\begin{array}{l}\text { Species and } \\
\text { year }\end{array}$} & \multicolumn{4}{c|}{ Kendall rank correlation coefficient } \\
\cline { 2 - 5 } & 5 & 7 & 9 & 11 \\
\cline { 2 - 5 } & & & & \\
& & & \\
Haddock 1993 & 0.25 & 0.43 & 0.28 & 0.23 \\
Haddock 1994 & 0.46 & 0.33 & 0.23 & 0.17 \\
Cod 1993 & 0.15 & 0.29 & 0.21 & 0.18 \\
Cod 1994 & 0.26 & 0.11 & 0.32 & 0.32 \\
\hline
\end{tabular}

Table 5. Melanogrammus aeglefinus and Gadus morhua. p-values from the test of independence of the Kendall rank correlation coefficients between observed and depthweighted modeled Chesson's preference index. ${ }^{*}$ Significant $(p<0.1)$

\begin{tabular}{|lcccc|}
\hline \multirow{2}{*}{$\begin{array}{l}\text { Species and } \\
\text { year }\end{array}$} & \multicolumn{5}{c|}{ p-value } \\
\cline { 2 - 5 } & 5 & 7 & 9 & 11 \\
\cline { 2 - 5 } & & & \multicolumn{4}{c|}{ Larval length $(\mathrm{mm})$} & \\
Haddock 1993 & $0.06^{*}$ & $0.00^{*}$ & $0.04^{*}$ & $0.08^{*}$ \\
Haddock 1994 & $0.00^{*}$ & $0.02^{*}$ & $0.08^{*}$ & 0.14 \\
Cod 1993 & 0.18 & $0.03^{*}$ & $0.10^{*}$ & 0.13 \\
Cod 1994 & $0.06^{*}$ & 0.25 & $0.03^{*}$ & $0.03^{*}$ \\
\hline
\end{tabular}


This finding does not contradict the dominance of $C$. finmarchicus nauplii in the diet of other stocks of larval haddock and cod such as the North Sea and Northeast Arctic populations (Heath \& Lough 2007). In more northern, colder regions, $C$. finmarchicus is the most abundant copepod, whereas the more southern species like Pseudocalanus spp. are low in abundance or absent (Heath \& Lough 2007). The prevalence of $C$. finmarchicus in these regions will increase its ingestion and thus preference. This pattern was also captured by the model, as the average preference for $C$. finmarchicus and O. similis increased in 1994 in conjunction with their increase in concentration. Similarly, average preference for Pseudocalanus spp. and Centropages typicus decreased in 1994 as their percentage of the total prey available dropped.

The preference of larval haddock and cod for Pseudocalanus spp. and the absence of similarly sized Centropages typicus from their guts is attributable to the superior escape ability (deformation rate threshold, escape speed, escape angle) of C. typicus. A siphon capture success of $86 \%$ supports the weak escape ability of Pseudocalanus spp. (Viitasalo et al. 2001). Though model parameters were taken from observations of escape behavior of Pseudocalanus spp. copepodites and $C$. typicus nauplii, studies of Temora longicornis show that escape speeds in $\mathrm{BL} \mathrm{s}^{-1}$ are equivalent for nauplii and copepodites (Titelman 2001) despite different body morphologies. Model parameters came from observations filmed at 50 frames $\mathrm{s}^{-1}$ (fps). Higherspeed video (1000 fps) observations have found escape speeds in the range of 200 to $400 \mathrm{BL} \mathrm{s}^{-1}$ (Buskey et al. 2002, Waggett \& Buskey 2007, Burdick et al. 2007), though not for the copepod species examined in the present study. Model simulations were repeated with 5 times greater species-specific escape speeds, such that they ranged from 290 to $450 \mathrm{BL} \mathrm{s}^{-1}$. At these speeds, advanced stages of copepods were nearly impossible to capture, resulting in negative growth rates, starvation, and average lengths of copepod eaten and total biomass found in the guts more than 1 SD below the observed mean. Copepodites and adults are found in the guts of larval haddock and cod, suggesting that the copepods are not escaping at their maximum capacity. Further investigation is required to verify that $C$. typicus escapes better than Pseudocalanus spp. under the same conditions and life stages. Yet another caveat of these studies is that most measured escape responses stimulated by a siphon or other near-field mechanical disturbance. Since escape reactions vary with the stimulus (Viitasalo et al. 1998, Burdick et al. 2007, Waggett \& Buskey 2007), a more accurate model would include measurements from attacks by larval cod and haddock.

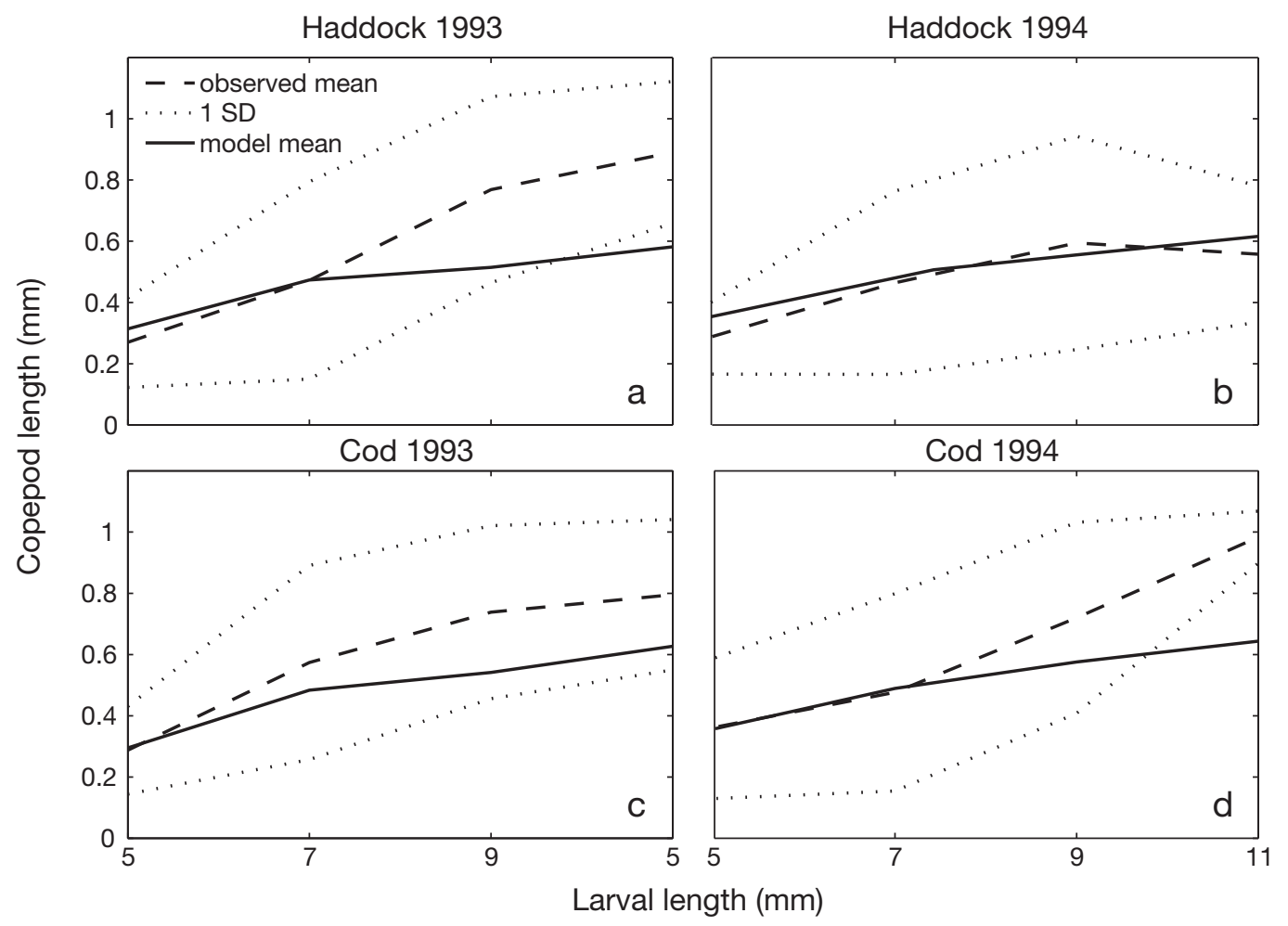

Fig. 10. Melanogrammus aeglefinus and Gadus morhua. Average length of copepod eaten by different sizes of (a,b) haddock and (c,d) cod larvae in 1993 and 1994 
In general, adding species-specific information on mouth size, metabolism, and length-weight relationship to a previously developed model for larval cod resulted in a novel foraging and growth model for larval haddock that agreed well with and helped explain observations on gut contents, prey preference, and growth. Adding detailed information on the feeding behavior of larval haddock to a model of larval cod was not necessary because there was no statistical difference in Chesson's preference index, biomass, or average length of copepods eaten by larval haddock and cod on Georges Bank in May of 1993 and 1994, with the exception of $5 \mathrm{~mm}$ larvae in 1994. The model was not very sensitive to changes in PF and PD behaviors. Doubling or halving $\mathrm{PF}$ and making corresponding changes to the PD produced differences in average length eaten that were 10 to $20 \times$ smaller than the SD of observations, and Chesson's preference indices that were up to $100 \times$ more different from observations than from each other. Also, alterations to PF and PD were
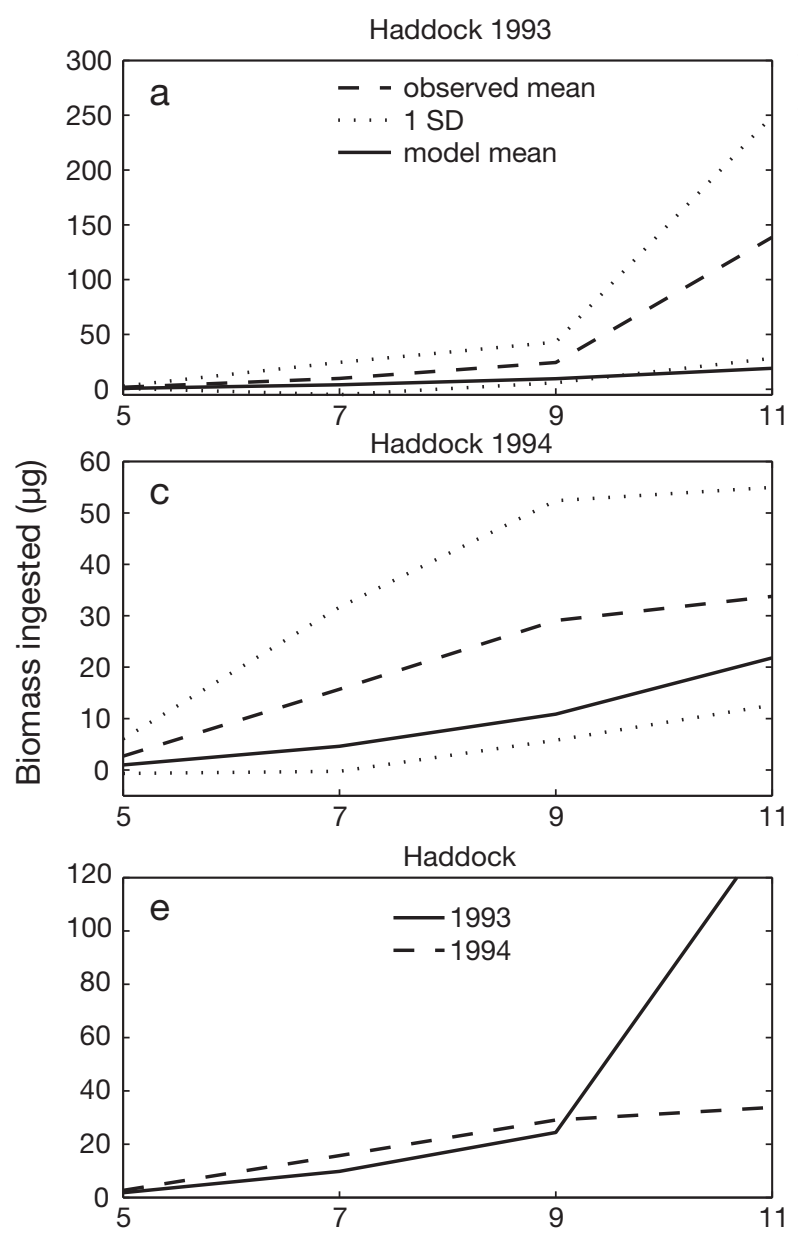

Larval length (mm)
Table 6. Melanogrammus aeglefinus. Mean growth rates observed (Lough et al. 1997) and modeled

\begin{tabular}{|llccc|}
\hline \multirow{2}{*}{ Year } & & \multicolumn{3}{c|}{ Mean growth rate $\left(\% \mathrm{~d}^{-1}\right)$} \\
\cline { 3 - 5 } & & 5 & 7 & 9 \\
& & 9.5 & 12.1 & 12.5 \\
1993 & Observed & 2.6 & 5.9 & 7.0 \\
1993 & Model & 5.0 & 10.0 & 10.6 \\
1994 & Observed & 3.8 & 7.0 & 8.2 \\
1994 & Model & & \\
\hline
\end{tabular}

Table 7. Gadus morhua. Mean growth rates observed (Lough et al. 2005) and modeled

\begin{tabular}{|c|c|c|c|c|}
\hline \multirow[t]{2}{*}{ Year } & & \multicolumn{3}{|c|}{ Mean \pm SD growth rate $\left(\% \mathrm{~d}^{-1}\right)$} \\
\hline & & 5 & 7 & 9 \\
\hline 1993 & Observed & $7.6 \pm 2.4$ & $11.3 \pm 3.3$ & $12.9 \pm 1.6$ \\
\hline 1993 & Model & 2.1 & 6.0 & 7.5 \\
\hline 1994 & Observed & 9.4 & $9.8 \pm 1.9$ & $10.4 \pm 2.0$ \\
\hline 1994 & Model & 3.4 & 7.1 & 8.8 \\
\hline
\end{tabular}
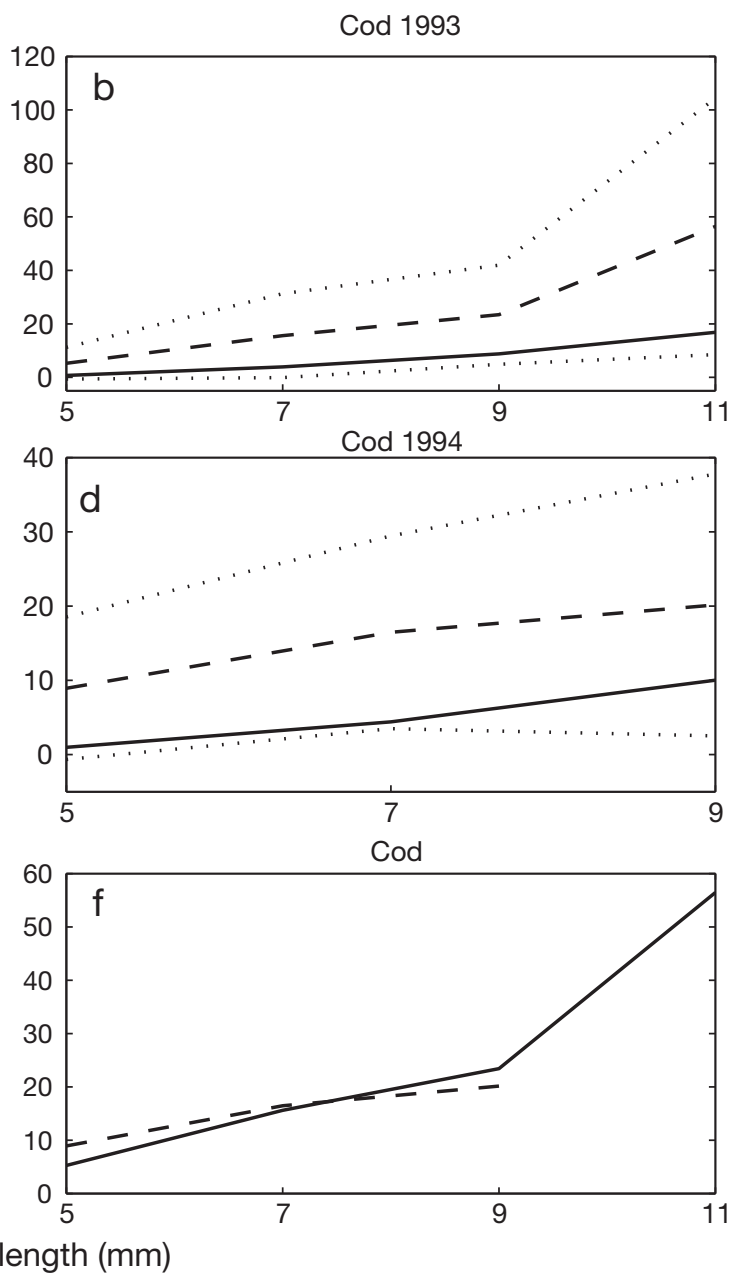

Fig. 11. Melanogrammus aeglefinus and Gadus morhua. Average biomass (dry wt) found in the guts of different sizes of $(\mathrm{a}, \mathrm{c})$ haddock and (b,d) cod larvae in (a,b) 1993 and (c,d) 1994. Observed mean biomass (dry wt) ingested by (e) haddock and (f) cod in 1993 (solid line) and 1994 (dashed line) 
not monotonic, such that percent error did not increase or decrease across all developmental stages of a copepod species. These findings suggest that fitting PF and PD parameters for haddock would not lead to improvement of the model in comparison to observations.

The differences in modeled probability of successful capture and average prey length eaten by the 2 species were explained by the mouth sizes of larval haddock and cod. For a given size class, the species with the larger mouth gape had the higher probability of successful capture and ate larger prey. Though there was no statistical difference in average prey length eaten by haddock and cod, modeled 9 to $15 \mathrm{~mm}$ haddock ate smaller prey than cod on average. Modeled Chesson's preference index corroborated that cod preferred later copepod stages more than haddock. In sum, these results suggest that the model can reproduce qualitative observations of cod eating later stages and larger prey than haddock.

The presence of larger prey in 1994 resulted in interannual differences in simulated average length eaten. Average lengths were 0.37 and $0.41 \mathrm{~mm}$ in 1993 and 1994 respectively (Broughton \& Lough in press). Increased average prey size in 1994 was due to fewer numbers of early-stage copepods and greater numbers of late-stage copepods. In 1994 there were more copepodites and adults of all 4 species (Lough et al. 2005).

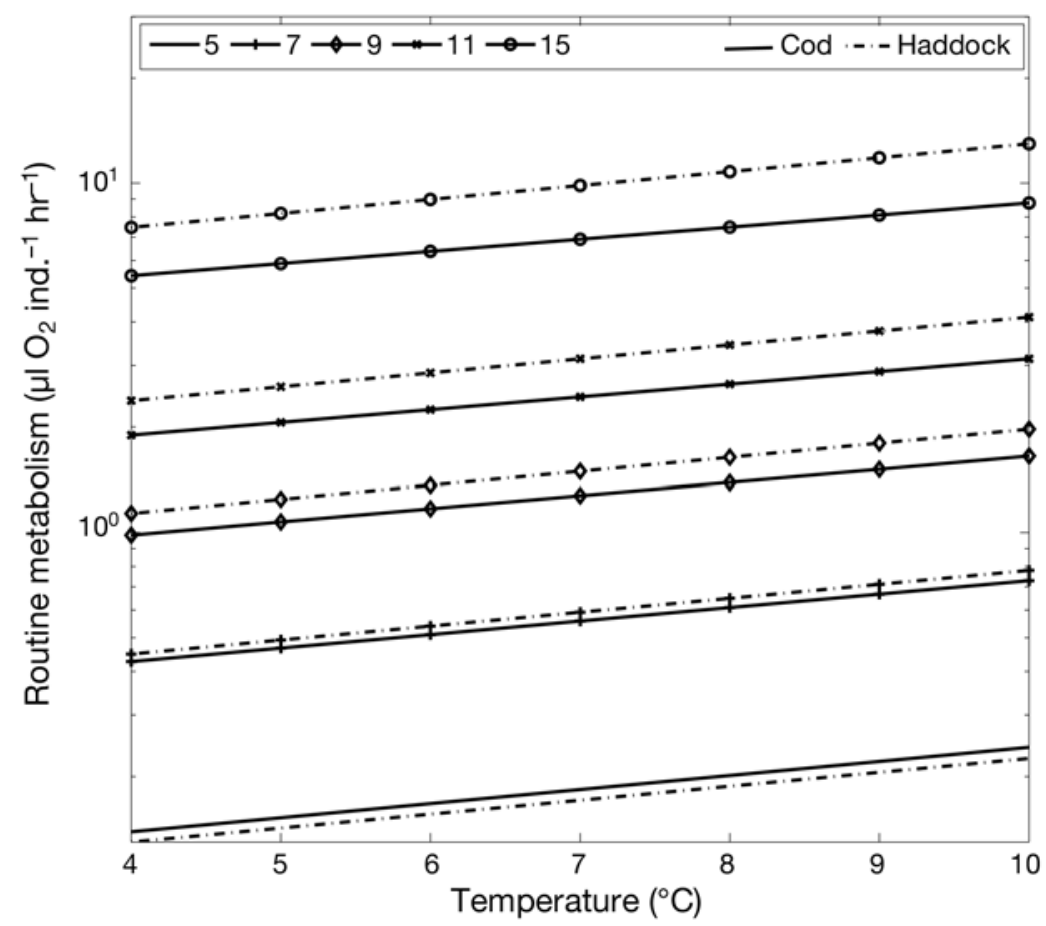

Fig. 12. Melanogrammus aeglefinus and Gadus morhua. Modeled routine respiration rate for haddock (from Lankin et al. 2008) and cod (from Lough et al. 2005) over a range of temperatures for 5, 7, 9, 11, and $15 \mathrm{~mm}$ larvae
Despite these differences, the average length of ingested copepods was not found to be statistically significant.

The model estimated the average prey length eaten by larval haddock and cod to within 1 SD of observations, but with a tendency to underestimate it. There are a few possibilities as to why the model underestimated the average prey length eaten. The first is that the escape abilities of the later stages of copepods were overestimated, leading to lower than accurate probabilities of capture success. Alternatively the foraging abilities of the larval fish (swimming speed, perception area, strike speed) could have been underestimated. A third explanation is that the adult female Pseudocalanus spp., the main prey observed in the guts of larger larvae and juveniles, carry egg sacs that increase their image area. If accounted for in the model, this difference in image area would lead to an increase in encounter and possibly ingestion of the Pseudocalanus spp. females.

The average biomass ingested in model simulations was also within $1 \mathrm{SD}$ of that observed but was underestimated. This could be the result of an underestimation of the average length of copepods eaten. This difference might also be reconciled by allowing larvae to vertically migrate such that they would be able to feed in dense patches of copepods and ingest more biomass at any one time.

Haddock ingested more biomass than cod, but still had lower growth rates (Fig. 8c-h). Differences in modeled growth rates were inversely related to the differences in respiration rates (Fig. 12). For a given size class, the species with the greater respiration rate had the lower growth rate. This was a result of the higher respiration rate incurring more metabolic costs, thereby reducing growth. The greater biomass ingested by haddock was not enough to offset its greater metabolic costs compared to cod. Respiration rate increases exponentially with temperature (Fig. 12), and as temperature increases a higher proportion of ingested energy is allocated to respiration rather than growth. However, in food-satiated conditions, growth also increases with temperature (Buckley et al. 2004). The greater average water temperature in 1994 (8 to $9^{\circ} \mathrm{C}$ ) compared to 1993 ( 7 to $8^{\circ} \mathrm{C}$; Lough et al. 2005) explains why the difference in growth rates between haddock and cod was greater in 1994 than in 1993 (Fig. 8e-h). Despite the increase in metabolic costs, the model predicted increased growth in 1994, 
suggesting that there was enough food ingested to support the increase in temperature.

It is likely the result of greater average temperature and prey biomass in 1994 that the simulations were unable to capture the observations of higher growth rates in 1993. The departure of model results from observations may be explained by the lack of vertical movement by the larvae, and will be examined in future work. Lough et al. (2005) found that greater growth rates in 1993 than 1994 for 7 and 9 mm larvae could be achieved by allowing the simulated larvae to follow the observed mean depth of the population and restricting their diet to only Pseudocalanus spp. Another contributing factor could be the difference in mean length of Pseudocalanus spp. adults between 1993 and 1994 (1.1 and $0.9 \mathrm{~mm}$ respectively; Broughton \& Lough in press), which was not represented in the model simulations. Additionally, predation on slower-growing larvae could have resulted in the observed growth rates. It should also be noted that the model-data mismatch is affected to some unknown degree by sampling error, given the inherent variability in plankton sampling. Though the growth rates from the larval haddock and cod simulations were lower than those observed, they were still realistic and would not result in larval death.

Mechanistic models like this one allow us to understand the how and why, rather than just predict what will happen under certain static conditions. Through the foraging model, we have learned that larval haddock and cod select the species and stages of copepods that are physically and behaviorally vulnerable to predation. Parameters and functions of these escape behaviors have been determined for the copepods Calanus finmarchicus, Pseudocalanus spp., Oithona similis, and Centropages typicus, all of which can be used in future studies of prey selection. Additional information on copepod escape behavior and defense morphology (spines, armor, etc.) may help to reconcile the differences between modeled and observed prey selection. Detailed information on prey selection and feeding behavior is necessary to model larval growth. Larval growth then determines survival through its effects on starvation, the ability to encounter and catch prey, and the ability to avoid predation. Ultimately, studies of larval fish survival will provide insights into recruitment dynamics.

The larval haddock and cod foraging models can be used to forecast the effect of climate change on larval haddock survival through associated changes in the size and quantity of food. The foraging model will be necessary for predicting the response of larval fish growth and survival should the copepod community composition be altered by climate change. For example, the mean size of copepods in the North Sea has decreased with increasing temperature since the 1980s, resulting in lower larval and juvenile cod survival (Beaugrand et al. 2003). Alternatively, Pitois \& Fox (2008) found that increased temperature and the correlated increased copepod biomass and decreased mean copepod size resulted in higher growth of first-feeding larval cod when modeled on the UK shelf region. On Georges Bank from 1977 to 2004, the abundance of dominant prey items Calanus finmarchicus, Pseudocalanus spp., Centropages typicus, and Oithona spp. were significantly correlated with temperature and/or salinity (Kane 2007). Though no direct relationship between climate effects and cod recruitment has been found through changes in the zooplankton (Pitois \& Fox 2008), changes in prey size and abundance can easily be incorporated into the cod and haddock foraging models to determine how well larvae will feed and grow under different conditions.

The IBM presented here is the first of its kind for haddock, as more emphasis has usually been placed on cod. Haddock represent a classic case of a recruitment-dominated fish stock, with relatively infrequent large year-classes dominating the population and fishable biomass at any given time (Brodziak et al. 2008). Compared to cod, haddock spawning is more restricted seasonally and spatially (Auditore et al. 1994, Lough et al. 2006), and larval haddock have a lower tolerance to variations in temperature and salinity (Laurence \& Rogers 1976). This combination of restricted spawning, sensitivity to environmental conditions, and dominant year-classes make haddock well suited as a model fish species for unraveling the factors controlling recruitment in fish populations.

In conclusion, our modeling study revealed that both larval haddock and cod demonstrate positive selection of Pseudocalanus spp. and negative selection of Calanus finmarchicus. Adding species-specific copepod behavior to the IBM explained the low selection for Centropages typicus by larval haddock and cod. Morphological and physiological information on larval haddock was sufficient to create a foraging and growth model that reproduced observed patterns of average prey length eaten and preference for the 4 main copepod prey species observed in the gut.

Acknowledgements. We thank A. Solow for help with statistical analysis. C.M.P. was supported by a WHOI Watson Fellowship. Partial support was provided by NOAA GLOBEC grant NA17RJ1223. This is contribution no. 614 of the NW Atlantic US GLOBEC program jointly funded by NOAA and NSF.

\section{LITERATURE CITED}

Auditore PJ, Lough RG, Broughton EA (1994) A review of the comparative development of Atlantic cod (Gadus morhua L.) and haddock (Melanogrammus aeglefinus L.) based on an illustrated series of larvae and juveniles from Georges Bank. NAFO Sci Counc Stud 20:7-18 
Bailey KM, Houde ED (1989) Predation on eggs and larvae of marine fishes and the recruitment problem. Adv Mar Biol 25:1-83

Beaugrand G, Brander KM, Lindley JA, Souissi S, Reid PC (2003) Plankton effect on cod recruitment in the North Sea. Nature 426:661-664

Bolz GR, Lough RG (1988) Growth through the first six months of Atlantic cod, Gadus morhua, and haddock, Melanogrammus aeglefinus, based on daily otolith increments. Fish Bull 86:223-235

Brodziak J, Traver ML, Col LA (2008) The nascent recovery of the Georges Bank haddock stock. Fish Res 94:123-132

Broughton EA, Lough RG (in press) General trends and interannual variability in prey selection by larval cod and haddock from the southern flank of Georges Bank, May 1993-1997. NOAA Tech Memo NMFS/NE

Buckley LJ, Durbin EG (2006) Seasonal and inter-annual trends in the zooplankton prey and growth rate of Atlantic cod (Gadus morhua) and haddock (Melanogrammus aeglefinus) larvae on Georges Bank. Deep-Sea Res II 53: 2758-2770

Buckley LJ, Caldarone EM, Lough RG (2004) Optimum temperature and food-limited growth of larval Atlantic cod (Gadus morhua) and haddock (Melanogrammus aeglefinus) on Georges Bank. Fish Oceanogr 13:134-140

Burdick DS, Hartline DK, Lenz PH (2007) Escape strategies in co-occurring calanoid copepods. Limnol Oceanogr 52: 2373-2385

Buskey EJ, Lenz PH, Hartline DK (2002) Escape behavior of planktonic copepods in response to hydrodynamic disturbances: high speed video analysis. Mar Ecol Prog Ser 235: 135-146

Caparroy P, Thygesen UH, Visser AW (2000) Modelling the attack success of planktonic predators: patterns and mechanisms of prey selectivity. J Plankton Res 22: $1871-1900$

> Chesson J (1978) Measuring preference in selective predation. Ecology 59:211-215

$>$ Davis CS (1984) Predatory control of copepod seasonal cycles on Georges Bank. Mar Biol 82:31-40

Davis CS (1987) Zooplankton life cycles. In: Backus RH, Bourne DW (eds) Georges Bank. MIT Press, London, p 1-593

Evans BI, O'Brien WJ (1988) A reevaluation of the search cycle of planktivorous Arctic grayling, Thamallus arcticus. Can J Fish Aquat Sci 45:187-192

Fields DM (2000) Characteristics of the high frequency escape reactions of Oithona sp. Mar Freshw Behav Physiol 34:21-35

Fields DM, Yen J (1997) The escape behavior of marine copepods in response to a quantifiable fluid mechanical disturbance. J Plankton Res 19:1289-1304

Fiksen $\varnothing$, MacKenzie BR (2002) Process-based models of feeding and prey selection in larval fish. Mar Ecol Prog Ser 243:151-164

Fiksen $\varnothing$, Utne ACW, Aksnes DL, Eiane K, Helvik JV, Sundby S (1998) Modelling the influence of light, turbulence and ontogeny on ingestion rates in larval cod and herring. Fish Oceanogr 7:355-363

Fiksen Ø, Jørgensen C, Kristiansen T, Vikebø F, Huse G (2007) Linking behavioural ecology and oceanography: larval behaviour determines growth, mortality and dispersal. Mar Ecol Prog Ser 347:195-205

- Finn RN, Ronnestad I, van der Meeren T, Fyhn HJ (2002) Fuel and metabolic scaling during the early life stage of Atlantic cod Gadus morhua. Mar Ecol Prog Ser 243: $217-234$
Galbraith PS, Browman HI, Racca RG, Skiftesvik AB, SaintPierre JF (2004) Effect of turbulence on the energetics of foraging in Atlantic cod Gadus morhua larvae. Mar Ecol Prog Ser 281:241-257

Greene CH, Landry MR, Monger BC (1986) Foraging behavior and prey selection by the ambush entangling predator Pleurobrachia bachei. Ecology 67:1493-1501

Grimm V, Railsback SF (2005) Individual based modeling and ecology. Princeton University Press, Princeton, NJ

Grimm V, Berger U, Bastiansen F, Eliassen S and others (2006) A standard protocol for describing individual-based and agent-based models. Ecol Modell 198:115-126

Hardy AC, Bainbridge R (1954) Experimental observations on the vertical migrations of plankton animals. J Mar Biol Assoc UK 33:409-448

> Haury LR, Kenyon DE, Brooks JR (1980) Experimental evaluation of the avoidance reaction of Calanus finmarchicus. J Plankton Res 2:187-202

Heath MR, Lough RG (2007) A synthesis of large-scale patterns in the planktonic prey of larval and juvenile cod (Gadus morhua). Fish Oceanogr 16:169-185

Houde ED (1987) Fish early life dynamics and recruitment variability. Am Fish Soc Symp 2:17-29

Hunt von Herbing I, Gallager SM (2000) Foraging behavior in early Atlantic cod larvae (Gadus morhua) feeding on a protozoan (Balanion sp.) and a copepod nauplius (Pseudodiaptomus sp.). Mar Biol 136:591-602

Ivlev VS (1961) Experimental ecology of feeding in fishes. Yale University Press, New Haven, CT

Kane J (1984) The feeding habits of co-occurring cod and haddock larvae from Georges Bank. Mar Ecol Prog Ser 16: 9-20

Kane J (2007) Zooplankton abundance trends on Georges Bank, 1977-2004. ICES J Mar Sci 64:909-919

Kiørboe T, Visser AW (1999) Predator and prey perception in copepods due to hydromechanical signals. Mar Ecol Prog Ser 179:81-95

> Kiørboe T, Saiz E, Visser A (1999) Hydrodynamic signal perception in the copepod Acartia tonsa. Mar Ecol Prog Ser 179:97-111

Kristiansen T, Fiksen $\varnothing$, Folkvord A (2007) Modelling feeding, growth, and habitat selection in larval Atlantic cod (Gadus morhua): observations and model predictions in a macrocosm environment. Can J Fish Aquat Sci 64: 136-151

> Kristiansen T, Jørgensen C, Lough RG, Vikebø F, Fiksen $\varnothing$ (2009a) Modeling rule-based behavior: habitat selection and the growth-survival trade-off in larval cod. Behav Ecol 20:490-500

Kristiansen T, Lough RG, Werner FE, Broughton EA, Buckley LJ (2009b) Individual-based modeling of feeding ecology and prey selection of larval cod on Georges Bank. Mar Ecol Prog Ser 376:227-243

Landry MR, Fagerness VL (1988) Behavioral and morphological influences on predatory interactions among marine copepods. Bull Mar Sci 43:509-529

> Lankin KF, Peck MA, Buckley LJ, Bengtson DA (2008) The effects of temperature, body size and growth rate on energy losses due to metabolism in early life stage of haddock (Melanogrammus aeglefinus). Mar Biol 155:461-472

Laurence GC (1985) A report on the development of stochastic models of food limited growth and survival of cod and haddock larvae on Georges Bank. In: Laurence GC, Lough RG (eds) Growth and survival of larval fishes in relation to the trophodynamics of Georges Bank cod and haddock. NOAA Tech Memo NMFS-F/NEC-36. National Marine Fisheries Service, NOAA, Woods Hole, MA, p 83-150 
Laurence GC, Rogers CA (1976) Effects of temperature and salinity on comparative embryo development and mortality of Atlantic cod (Gadus morhua L.) and haddock (Melanogrammus aeglefinus L.). J Cons Int Explor Mer 36:220-228

Leis JM (2007) Behaviour as input for modelling dispersal of fish larvae: behaviour, biogeography, hydrodynamics, ontogeny, physiology and phylogeny meet hydrography. Mar Ecol Prog Ser 347:185-193

Lough RG, Mountain DG (1996) Effect of small-scale turbulence on feeding rates of larval cod and haddock in stratified water on Georges Bank. Deep-Sea Res II 43: 1745-1772

Lough RG, Caldarone EM, Buckley LJ, Broughton EA, Kiladis ME, Burns BR (1997) A comparative study of feeding, condition, and growth of larval cod and haddock on southern Georges Bank, May 1993 vs. May 1994. ICES CM Doc 1997/T:41. ICES, Copenhagen

> Lough RG, Buckley LJ, Werner FE, Quinlan JA, Pehrson Edwards K (2005) A general biophysical model of larval cod (Gadus morhua) growth applied to populations on Georges Bank. Fish Oceanogr 14:241-262

Lough RG, Hannah CG, Berrien P, Brickman D, Loder JW, Quinlan JA (2006) Spawning pattern variability and its effect on retention, larval growth and recruitment in Georges Bank cod and haddock. Mar Ecol Prog Ser 310: 193-212

MacKenzie BR, Kiørboe T (1995) Encounter rates and swimming behavior of pause-travel and cruise larval fish predators in calm and turbulent laboratory environments. Limnol Oceanogr 40:1278-1289

MacKenzie BR, Kiørboe T (2000) Larval fish feeding and turbulence: a case for the downside. Limnol Oceanogr 45:1-10

MacKenzie BR, Miller TJ, Cyr S, Leggett WC (1994) Evidence for a dome-shaped relationship between turbulence and larval fish ingestion rates. Limnol Oceanogr 39:1790-1799

Mariani P, MacKenzie BR, Visser AW, Botte V (2007) Individual-based simulations of larval fish feeding in turbulent environments. Mar Ecol Prog Ser 347:155-169

Mauchline J (1998) The biology of calanoid copepods. In: Blaxter JHS, Southward AJ, Tyler PA (eds) Advances in marine biology, Vol 33. Academic Press, London, p 400-420

McGillicuddy DJ Jr, Bucklin A (2002) Intermingling of two Pseudocalanus species on Georges Bank. J Mar Res 60: 583-604

Munk P (1995) Foraging behavior of larval cod (Gadus morhua) influenced by prey density and hunger. Mar Biol 122:205-212

- Munk P (1997) Prey size spectra and prey availability of larval and small juvenile cod. J Fish Biol 51:340-351

> Naimie CE (1996) Georges Bank residual circulation during weak and strong stratification periods: prognostic numerical model results. J Geophys Res 101:6469-6486

> Otterå H, Folkvord A (1993) Allometric growth in juvenile cod (Gadus morhua L.) and possible effects on cannibalism. J Fish Biol 43:643-645

Pepin P, Penney R (2000) Feeding by a larval fish community: impact on zooplankton. Mar Ecol Prog Ser 204: $199-212$

Pitois SG, Fox CJ (2008) Empirically modelling the potential effects of changes in temperature and prey availability on the growth of cod larvae in UK shelf seas. ICES J Mar Sci 65:1559-1572

Rothschild BJ, Osborn TR (1988) Small-scale turbulence and plankton contact rates. J Plankton Res 10:465-474
Rowlands WL, Dickey-Collas M, Geffen AJ, Nash RDM (2006) Gape morphology of cod Gadus morhua (L.), haddock Melanogrammus aeglefinus (L.) and whiting Merlangius merlangus (L.) through metamorphosis from larvae to juveniles in the western Irish Sea. J Fish Biol 69: 1379-1395

Rowlands WL, Dickey-Collas M, Geffen AJ, Nash RDM (2008) Diet overlap and prey selection through metamorphosis in Irish Sea cod (Gadus morhua), haddock (Melanogrammus aeglefinus), and whiting (Merlangius merlangus). Can J Fish Aquat Sci 65:1297-1306

Ruzicka J (2004) Integrating bioenergetics and foraging behavior: the physiological ecology of larval cod (Gadus morhua). PhD dissertation, Woods Hole Oceanographic Institution

> Ruzicka JJ, Gallager SM (2006a) The importance of the cost of swimming to the foraging behavior and ecology of larval cod (Gadus morhua) on Georges Bank. Deep-Sea Res II 53: $2708-2734$

> Ruzicka JJ, Gallager SM (2006b) The saltatory search behavior of larval cod (Gadus morhua). Deep-Sea Res II 53: $2735-2757$

Skartveit A, Olseth JA, Tuft ME (1998) An hourly diffuse fraction model with correction for variability and surface albedo. Sol Energy 63:173-183

Sundby S, Bjørke H, Soldal AV, Olsen S (1989) Mortality rates during the early life stages and year-class strength of the north-east Arctic cod (Gadus morhua L.). Rapp P-V Reun Cons Int Explor Mer 191:351-358

Svensen C, Kiørboe T (2000) Remote prey detection in Oithona similis: hydromechanical versus chemical cues. J Plankton Res 22:1155-1166

Tiselius P, Jonsson PR (1990) Foraging behavior of six calanoid copepods: observations and hydrodynamic analysis. Mar Ecol Prog Ser 66:23-33

Titelman J (2001) Swimming and escape behavior of copepod nauplii: implications for predator-prey interactions among copepods. Mar Ecol Prog Ser 213:203-213

> Titelman J, Kiørboe T (2003) Predator avoidance by nauplii. Mar Ecol Prog Ser 247:137-149

> Utne-Palm AC (1999) The effect of prey mobility, prey contrast, turbidity and spectral composition on the reaction distance of Gobiusculus flavescens to its planktonic prey. J Fish Biol 54:1244-1258

> Viitasalo M, Kiørboe T, Flinkman J, Pedersen LW, Visser AW (1998) Predation vulnerability of planktonic copepods: consequences of predator foraging strategies and prey sensory abilities. Mar Ecol Prog Ser 175:129-142

Viitasalo M, Flinkman J, Viherluoto M (2001) Zooplanktivory in the Baltic Sea: a comparison of prey selectivity by Clupea harengus and Mysis mixta, with reference to prey escape reactions. Mar Ecol Prog Ser 216: 191-200

> Vikebø F, Jørgensen C, Kristiansen T, Fiksen Ø (2007) Drift, growth and survival of larval Northeast Arctic cod with simple rules of behaviour. Mar Ecol Prog Ser 347: 207-219

Waggett RJ, Buskey EJ (2007) Calanoid copepod escape behavior in response to a visual predator. Mar Biol 150: 599-607

> Werner FE, Perry RI, Lough RG, Naimie CE (1996) Trophodynamic and advective influences on Georges Bank larval cod and haddock. Deep-Sea Res II 43:1793-1822

> Yen J, Lenz P, Gassie DV, Hartline DK (1992) Mechanoreception in marine copepods: electrophysiological studies on the first antennae. J Plankton Res 14:495-512 